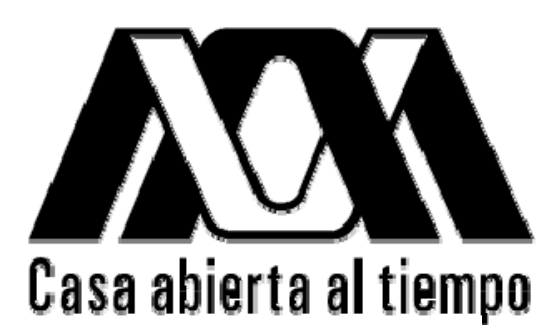

UNIVERSIDAD AUTÓNOMA METROPOLITANA

UNIDAD IZTAPALAPA

DIVISIÓN DE CIENCIAS SOCIALES Y HUMANIDADES

POSGRADO EN CIENCIAS ANTROPOLÓGICAS

Apropiación de la computadora y la red Internet en la vida cotidiana.

Aproximaciones teóricas y empíricas para su estudio.

Estudio de caso: los jóvenes universitarios tecno-letrados.

Gladys Ortiz Henderson

Tesina de Maestría en Ciencias Antropológicas

Director: Dra. Larissa Adler Lomnitz

Asesores: Dr. Raúl Nieto Calleja

Dra. Delia Crovi Druetta

México, D.F.

Junio, 2007 


\section{Apropiación de la computadora y la red Internet en la vida cotidiana Aproximaciones teóricas y empíricas para su estudio Estudio de caso: los jóvenes universitarios tecno-letrados Gladys Ortiz Henderson}

Introducción

1. La vida cotidiana: producción y reproducción de lo social

1.1 La noción de apropiación

1.2 El sentido: la construcción del significado en la vida cotidiana

2. Medios de comunicación en la vida cotidiana

2.1 Los medios de comunicación como artefactos tecnológicos

2.2 Los medios de comunicación como portadores de contenidos culturales

2.3 El caso de la red Internet: la construcción de la cultura virtual

3. La modernidad como marco macro-estructural de la vida cotidiana

3.1 Características de la modernidad

3.2 Medios de comunicación y modernidad

3.3 Los jóvenes

4. Aproximaciones al campo

4.1 Jóvenes estudiantes de una universidad privada

4.1.1 Acceso a la computadora: mamás y papás ponen la tecnología a su alcance

4.1.2 Acceso a la computadora: gracias a la red social

4.1.3 La computadora: el papel de la escuela como mediadora

4.1.4 Primer contacto con la red: carácter lúdico

4.2 Un grupo comparativo: jóvenes estudiantes de una universidad pública

4.2.1 Acceso a la computadora: mamás y papás lo consideran un "gasto fuerte"

4.2.2 Acceso a la computadora: gracias a la red de amigos y familiares

4.2.3 Primer contacto con la red: la red "pirata"

4.3 Apropiación de la computadora y la red Internet en la vida cotidiana

4.3.1 Anclaje en la vida offline

4.3.2 La red Internet como constructora de identidad generacional

4.3.3 El tiempo (o la falta de) una constante

4.3.4 Movilidad y/o mantenimiento de la condición social

4.3.5 Representación colectiva: rechazo y alabanzas a las tecnologías

4.3.6 La computadora, la red Internet y otros medios de comunicación

5. Conclusiones

6. Apéndice. La computadora y la red Internet

6.1 Historia de la computadora y la red Internet

6.2 Historia en México

7. Glosario

8. Bibliografía 


\title{
Apropiación de la computadora y la red Internet en la vida cotidiana Aproximaciones teóricas y empíricas para su estudio Estudio de caso: los jóvenes universitarios tecno-letrados
}

\author{
La buena comprensión de los principios de la antropología sirven \\ para abarcar los procesos sociales de nuestro tiempo y puede \\ indicarnos, si estamos dispuestos a aprender de sus enseñanzas, \\ lo que debe hacerse y lo que debe evitarse. \\ Franz Boas
}

\section{Introducción}

En la actualidad la computadora y la red Internet son parte ya de nuestra vida cotidiana. Muchas personas cuentan con su PC o su Lap Top en casa, otras acuden al café Internet para revisar sus correos electrónicos, en las escuelas primarias se enseña computación a las niñas y niños y otros más saben lo que son estas nuevas tecnologías de la información y comunicación debido a anuncios espectaculares, publicidad, aparadores de las tiendas o a programas de televisión. Es tan natural el que existan las computadoras y la red Internet en el presente -y los avances tecnológicos en general, como los teléfonos celulares o la televisión- que un joven de 19 años, al ver mi interés en este tema, me preguntó: ¿por qué la gente grande está tan interesada en esto del cambio tecnológico y las computadoras si a mi y los de mi generación se me hace algo tan normal? ¿Qué tiene de importante?, no entiendo. $\mathrm{Y}$ es que la difusión de las llamadas nuevas tecnologías de la información -y de la tecnología en general- a partir de la Segunda Guerra Mundial ha tenido un acelerado avance con la aparición de los satélites, los transistores, la microelectrónica, etc., y más aún, a finales del siglo XX y principios del XXI. Según Sonia Livingstone, en la historia de las tecnologías de la información Internet ha sido el más rápido en cuanto a difusión: en Estados Unidos en 1990 se empezó con unas cuantas personas y para 1997 ya había 19 millones de estadounidenses usando la Internet, para 1999 ya había más de 100 millones (Livingstone, 2002: 33). El ejemplo del número de usuarios de la red Internet en México pasó de 14.9 millones en el 200 a 17.1 millones de usuarios mayores de seis años en el cierre del año 2005 (AMIPCI 2005).

Evidentemente para las generaciones más jóvenes el acudir a un café Internet y pasar horas delante de un monitor de computadora es parte de la vida diaria como el ir a la escuela, comer, ver la televisión o acudir al trabajo en algún medio de transporte, pero 
no es así para las generaciones que antes utilizábamos máquinas de escribir para realizar las tareas o el teléfono de disco para llamar a nuestros familiares. Al respecto una persona de mi edad comentó: ¡Quién iba a pensar que íbamos a traer un teléfono inalámbrico que manda mensajitos? Si nos hubieran dicho antes, hubiéramos pensado: ‘¿cómo?, ¿y el cable?’ ¡Y ahora dependemos totalmente de él!. Mi interés surgió entonces de ver cómo en la actualidad existe una marcada distancia entre generaciones que se acentúa aún más con el uso de las tecnologías informacionales, de ver cómo los más jóvenes usan, manipulan, se apropian, se divierten con el uso de la computadora y la red Internet, pero no solamente eso, sino de ver cómo el celular -y otras tecnologíasse han convertido en parte esencial de su vida diaria. Cuando le pregunté a un estudiante universitario, ¿qué tan importante era la tecnología de la información para él me respondió: Mira: así de importante, mostrándome que su celular estaba lleno de mensajes de 'Elsa', su novia, mensajes que habían sido enviados y respondidos el mismo día, siendo apenas las 11 de la mañana, No podría vivir sin celular, concluyó.

Mi interés surgió del extrañamiento de lo familiar (las tecnologías que están por todos lados) pero de la distancia en cuanto a la edad (generación), quizás de una cualidad antropológica que indica “el hacer extraño lo familiar” así como también “familiarizarte con lo extraño”. Perteneciente a una generación que ha vivido el abrupto y a la vez casi imperceptible cambio que la computadora y la red Internet han traído aparejados, como comunicóloga y posible antropóloga, y en constante contacto con estudiantes universitarios jóvenes comencé a preguntarme si la tecnología de la información, específicamente la computadora y la red Internet, habían traído cambios importantes y significativos en la vida de la gente, sobre todo de los jóvenes con quienes he tenido constante contacto últimamente por cuestiones de trabajo. Mi pregunta de investigación entonces se centró, en un primer momento en: ¿Cómo los jóvenes se han adaptado y han adoptado estas nuevas tecnologías de la información y la comunicación? ¿Cómo las están usando en su vida cotidiana? ¿Cómo se apropian de éstas? ¿Qué sentido le dan a estas tecnologías?

En la literatura revisada sobre Internet y nuevas tecnologías, en el campo de las ciencias de la comunicación y la antropología, e incluso de la sociología, este es el enfoque que ha sido mayormente abordado: el ver a la tecnología como un generador de cambios en los entornos sociales. En el campo de las ciencias de la comunicación, el enfoque 
llamado mediacéntrico (McQuail, 1991) ha atribuido a la tecnología y a los medios de comunicación un papel central en la generación de cambios en las conductas, actitudes y comportamientos de las personas, desde la teoría de la aguja hipodérmica hasta la teoría de los efectos a largo plazo ${ }^{1}$ e incluso en la teoría crítica clásica, se ha visto a las personas como meros receptáculos de contenidos y mensajes, como seres ontológicamente inactivos. En la antropología -siendo relativamente pocas las ocasiones en que se trata a la tecnología como objeto de estudios ${ }^{2}$ - también se ha conceptualizado a la tecnología como un proyectil que golpea ambientes culturales, sociales, políticos y económicos causando un impacto en éstos (Santos y Díaz, 1997: 48) y, finalmente, en la sociología el enfoque predominante ha sido el ver a la tecnología como "agente de cambio" (Surrat, 2001: 4), incluso con un peso tal, que se indica que la característica especial de la sociedad actual es el ser una informacional (Castells, 1999).

Este tipo de enfoques ha tenido una gran cantidad de críticas por ver a los sujetos sociales como pasivos, como determinados por las estructuras sociales en las que viven, en este caso las instituciones mediáticas o tecnológicas, y sin posibilidad alguna de generar un cambio. Alternativas a este tipo de enfoques han sido en ciencias de la comunicación, la hipótesis de los usos y gratificaciones (Wolf, 1994), la cual pone el acento en el individuo como actor y productor activo de mensajes en el momento de estar en contacto con un medio de comunicación y, en antropología, la construcción social de la tecnología, que se centra también en el individuo, el usuario de la tecnología, y trata de poner al medio o tecnología en el contexto mismo de construcción a través de sus cuatro categorías principales: los grupos sociales relevantes, la flexibilidad interpretativa, los mecanismos de cierre y el esquema tecnológico (Santos y Díaz, 1997). Este tipo de punto de partida epistemológico, centrado en los individuos y la cotidianidad, lo pude verificar con mis primeras aproximaciones al campo. En las observaciones exploratorias pude constatar que la realidad social es mucho más

\footnotetext{
${ }^{1}$ La teoría de la aguja hipodérmica o ‘bullet theory’ de principios del siglo XX indicaba que las masas recibían el mensaje de los medios de comunicación de manera directa y sin mediación alguna como una 'bala' o inyección. Asimismo, en los años setenta y ochenta del siglo XX los estudios, centrados nuevamente en los medios, indicaron que si bien los medios tenían efectos en la gente éstos se daban a lo largo de la vida, a través del contacto constante con los medios de comunicación (Wolf, 1994)

${ }^{2}$ Incluso cuando el campo de estudios de la antropología abarca necesariamente a la tecnología, veamos por ejemplo, la definición de Margaret Mead "El antropólogo se ocupa de las relaciones recíprocas entre la naturaleza humana, el ambiente natural del hombre, sus invenciones tecnológicas, su organización social y las estructuras simbólicas de la religión, el arte y la filosofía, mediante las cuales se dota a la vida de valor y sentido” (Mead, 1995).
} 
compleja y que al centrarse en la tecnología (o medio de comunicación) como causa única se pierde la gran variedad de manifestaciones prácticas, materiales y simbólicas, que tecnologías como la computadora y la red Internet pueden tener. La tecnología no determina la sociedad ya que muchos factores intervienen, como la iniciativa personal, la innovación tecnológica, las aplicaciones sociales, etc. Asimismo, como Christine Hine, opino que "el agente de cambio no es la tecnología en sí misma, sino los usos y la construcción de sentido alrededor de ella...” (Hine, 2004: 13).

Finalmente, entre los discursos sobre la “sociedad de la información”, también conocida como "sociedad del conocimiento" (Crovi, 2002: 18) están aquellos que han incorporado el tema de la brecha digital, el cual se refiere a que si bien las tecnologías de la comunicación y de la información están siendo utilizadas cada día por una mayor cantidad de individuos en el mundo -quienes por lo mismo tienen pleno acceso a la información y al conocimiento generado por la humanidad- existe aún una gran cantidad de individuos, sobre todo en los países subdesarrollados como México, que no tienen pleno acceso a estas tecnologías. Las estrategias que hasta el momento han utilizado los organismos internacionales y gobiernos para combatir la brecha digital son: el incorporar más infraestructura tecnológica en las regiones menos favorecidas y el brindar capacitación para que todos los individuos puedan utilizarla. Sin embargo, es una realidad el que una gran cantidad de personas en el mundo están al margen del uso de las tecnologías de la información.

Por otro lado, aunque en la actualidad el uso de tecnologías como la red Internet o la computadora se convierte en una necesidad y obligación para todos, los más jóvenes son aquellos que han encontrado en éstas una forma de construir su identidad de jóvenes más allá de las designaciones “dominantes” de ser joven; de establecer códigos que los diferencian del mundo adulto y que, asimismo, los diferencian de los niños; son sobre todo los jóvenes quienes han incorporado de manera normal el uso de la computadora y la red Internet, tecnologías emblemáticas de los valores de la modernidad como la racionalización, la fragmentación y la objetivación, que son, sin embargo, adaptadas a su propio estilo de vida, su vida cotidiana, su subjetividad.

En uno de los primeros acercamientos al campo para enumerar a través de una encuesta exploratoria los usos que los estudiantes universitarios de primer semestre de la carrera 
de ciencias de la comunicación hacían de la red Internet en una universidad privada, cuya característica fundamental es el uso de nuevas tecnologías, me sorprendió el encontrar que si bien los estudiantes en su mayoría consideraban a Internet como lo máximo, una herramienta que me va a servir toda mi vida o lo mejor, hubo un estudiante que expresó su aversión al medio al indicar que era un medio muy nuevo al que tengo que encontrarle el gusto para poder utilizarlo. En un segundo acercamiento al campo, al realizar observación participante en una familia de clase media en la CTM Culhuacán, familia formada por el padre, la madre, un hijo y una hija, me encontré con que el hijo mayor de 15 años -a diferencia de otras etnografías que se han realizado sobre los usos de tecnologías en donde los jóvenes varones son quienes más utilizan las tecnologías (Morley, 1996: 348-350) - no mostraba mucho interés por el uso de Internet y su conocimiento de ésta era mínimo. Finalmente, en un tercer acercamiento al campo tuve la oportunidad de conocer a un grupo de blogueros para quienes navegar por la Internet, escribir diariamente en su blog, socializar y participar activamente en línea era parte fundamental en su vida cotidiana a tal grado que el día que no escriben un "post” tienden a sentirse mal y llegan a pedir disculpas en línea. Para complejizar aún más el abordaje del fenómeno de las nuevas tecnologías, después del trabajo de campo llevado a cabo durante algunos meses del año 2006, nuevas preguntas surgieron:

¿Cuáles son las determinaciones estructurales que se presentan en esta relación joventecnología en la vida cotidiana? ¿De qué modo afecta Internet a las relaciones sociales en el tiempo y el espacio? ¿Es distinta esa organización a la de la vida real? ¿Cómo los jóvenes reconcilian lo virtual con lo real? ¿Es 'lo virtual' experimentado como algo radicalmente diferente y separado de 'lo real'? ¿Hay una frontera divisoria entre la vida online y la offline?

En los siguientes capítulos trabajaré con algunos conceptos y teorías que pueden ser de utilidad para el tratamiento del tema que he planteado. Asimismo, adelantaré parte del trabajo de campo que he venido realizando desde hace tiempo. 


\section{La vida cotidiana: producción y reproducción de lo social}

La pregunta inicial: ¿cómo los jóvenes se han adaptado y han adoptado estas nuevas tecnologías de la información y la comunicación?, indica un punto de partida preciso, el de la vida cotidiana. Esto implica cierto punto de vista epistemológico y metodológico en el que la unidad de análisis está inmersa en el devenir de la vida diaria, el vivir de todos los días de los jóvenes. Desde este punto de partida, la tecnología como la computadora y la red Internet, se vuelve una parte más de la trama cotidiana y no precisamente el centro (o el único centro) de atención en la investigación ${ }^{3}$. Aunque el acento está puesto en las situaciones de relación entre sujeto (joven) y tecnología, también se presentan como parte de la vida diaria su relación con la familia, la escuela, los amigos, fiestas, etc. A continuación mencionaré brevemente algunas perspectivas teóricas que han dilucidado la noción de “vida cotidiana” en las ciencias sociales.

En primer lugar, la vida cotidiana se teoriza como el espacio en el que se produce y/o se reproduce la sociedad día con día, es decir, se imagina como un mundo dinámico concebido como diferente a aquél que corresponde a toda la sociedad en su conjunto o a la estructura social, como una modalidad de la vida social. La noción de vida cotidiana tiene cabida en las teorías sociales que corresponden al nivel 'micro-esctructural' que se contraponen a las teorías del nivel 'macro-estructural'; el primero se refiere al nivel en el que se producen las interacciones, las situaciones y las actividades entre los individuos -la parte cambiante de la sociedad-, mientras que el segundo nivel hace referencia a lo permanente o estático, a las instituciones, los estratos sociales, la clase social, la cultura, la economía, etc. ${ }^{4}$ Se puede decir, asimismo, que la vida cotidiana es

\footnotetext{
${ }^{3}$ Quisiera señalar, como se verá más adelante en este escrito, que cuando se toma al medio de comunicación o a la tecnología como objeto de estudio -en una postura "mediacéntrica" como se le denomina- se suele caer en atribuir a éste ciertos cambios en la vida social o cultural. Se considera qué ésta puede generar cambios tanto en la vida cotidiana de los individuos o, incluso, en las estructuras sociales generando nuevas formaciones sociales. Desde este panorama el individuo aparece reducido y condicionado a las características intrínsecas a cada tecnología, como ente "pasivo" ante los cambios tecnológicos. En otras palabras, la tecnología aparece como una "estructura" que determinaría la "vida cotidiana" de los individuos.

${ }^{4}$ El estudio del nivel micro-estructural de la sociedad ha estado ligado en su origen al grupo de sociólogos de la Escuela de Chicago de principios del siglo XX. Los miembros del departamento de sociología de la Escuela de Chicago, fundada en 1892, como Robert Ezra Park, W. I. Thomas y Florian Zananieci, se centraron en el estudio de la vida urbana y las interacciones sociales, en específico, en los problemas cotidianos y en las experiencias vividas en la ciudad. Es famoso el estudio llevado a cabo por W. I. Thomas y F. Zananiecki (1958) The Polish Peasant in Europe and America, que se centra en los significados individuales sobre la vida social y las relaciones entre ciertos tipos de personalidades y los grandes cambios sociales o la aseveración de R. E. Park de que "es en la mente del hombre marginal -donde los cambios y las fusiones de la cultura ocurren- en donde nosotros podemos estudiar mejor los procesos de la civilización y el progreso” (Park, 1928: 893 en Roberts, 2006 :17). Sin embargo, es en los años sesenta cuando comienza la preocupación o la moda por la vida cotidiana, debido al surgimiento de movimientos
} 
el espacio natural en el que los antropólogos llevan a cabo generalmente el trabajo etnográfico.

En ciencias sociales se ha reflexionado sobre la noción de vida cotidiana desde dos puntos de vista diferentes: como un espacio determinado por la estructura social -y por lo tanto lugar de reproducción- o, por el contrario, como el espacio creativo en donde tiene lugar la creación social en donde los individuos, en su actuar diario, influyen en la historia y en la sociedad en general, es decir, es un espacio en el que se lleva a cabo la producción social. Dentro de la primera postura, centrada en la estructura social -y conciente de la simplificación de esta dicotomía- se ha ubicado al sociólogo Emile Durkheim, mientras que se ha relacionado a Max Weber con la segunda postura relativa a la acción individual.

Agnes Heller, siguiendo a Luckács (León, 1999: 33-38), teoriza la vida cotidiana como un espacio en el que los individuos llevan a cabo la reproducción social y la satisfacción de sus necesidades: "todas las capacidades fundamentales, los afectos y los modos de comportamiento fundamentales con los cuales trasciendo mi ambiente y que yo remito al mundo ‘entero’ alcanzable por mí y que yo objetivo en este mundo, en realidad yo me los he apropiado en el curso de la vida cotidiana” (Heller 1977: 25 en Adame 2005) . La vida cotidiana, aunque es un proceso, está determinada por la historia, y los individuos no se pueden dar cuenta de esta determinación más que objetivando sus relaciones a través del trabajo. La vida cotidiana es, por lo tanto, el reflejo de las estructuras sociales y las formas de apropiación que éstas imponen, lo que conducen a una forma de homogeneización social. Agnes Heller tiene en mente, desde una postura marxista, la estructura de la sociedad capitalista que se manifiesta en el fluir de las relaciones cotidianas entre hombres y mujeres.

También dentro de esta postura crítica se puede citar a Habermas quien también concibe el espacio de la vida cotidiana o 'el mundo de vida' dentro del marco del sistema capitalista. La creciente racionalización del mundo de la vida es paralela a la creciente racionalización sistémica, éste último coloniza el mundo de la vida en detrimento de la libertad del individuo. Considera que este mundo cotidiano tiene, sin embargo, un

hippies, el feminismo, la ecología y la influencia de la sociología fenomenológica de Schutz como opción para la construcción de la propia realidad (Flecha et al., 2001: 58). 
carácter emancipador ya que a través de la acción comunicativa entre los sujetos se puede cerrar la brecha entre la esfera de validez sistémica y la esfera de la vida cotidiana.

Por otro lado, la noción de vida cotidiana de Erwing Goffman tiene como base o unidad de análisis las interacciones entre los individuos, las cuales, más que ser producto de determinaciones estructurales, son resultado de las contingencias situacionales y de las normas, posiciones y roles de los actores en una situación dada. La estructura social se ve en Goffman desdibujada para dar cabida a "las formas de vida relativamente autónomas” que expresa la interacción cotidiana (León 1999: 57). La vida cotidiana para Goffman, sin embargo, tiene que ver con la idea de la reproducción social, ya que privilegia el proceso de mantenimiento y continuidad social dejando de lado el cambio, la flexibilidad y el conflicto (Goffman, 1989).

En una postura intermedia se encontraría el socio-psicólogo Henri Tajfel. Para Tajfel, es a través de los procesos de categorización social (clasificación) como se puede observar el papel de las determinaciones sociales. Si bien indica que hay una determinación social para la percepción e interpretación del mundo, hay también espacios para el desacuerdo y la diferencia, ya que "la sola percepción de que se es diferente y el hecho de que ello se asuma como natural, puede hacer que los sujetos se vean imposibilitados a verse a sí mismos como pertenecientes a una determinada categoría, y, a pesar de ello, a relacionarse con otras categorías sociales en función de estas diferencias” (León, 1999: 51). En otras palabras, a partir del proceso de construcción de la identidad social plantea la posibilidad generativa y no solamente reproductiva de la vida social en la cotidianidad.

En un intento de posición intermedia cabe mencionar al sociólogo Pierre Bourdieu para quien los individuos no son un engranaje más dentro de la maquinaria de la reproducción, sino que tienen la capacidad de recrear sus circunstancias sin estar aislados de las relaciones estructurales. El concepto de habitus permite a Bourdieu escapar de la dicotomía entre estructuras determinantes y acción individual, ya que el habitus es un sistema de disposiciones adquiridas mediante el aprendizaje que constituye el mediador entre los comportamientos individuales y las condiciones objetivas. Para Bourdieu “los habitus son principios generadores de prácticas distintas y 
distintivas (...) pero también son esquemas clasificatorios, principios de clasificación, principios de visión y de división, aficiones diferentes. Establecen diferencias entre lo que es bueno y lo que es malo, entre lo que está bien y lo que está mal, entre lo que es distinguido y lo que es vulgar...” (Bourdieu, 2002: 20). El habitus, diría Bourdieu, es hablar de lo social y colectivo, pero también de lo individual o subjetivo.

Sin centrar el objeto en ver qué determina a qué, si las estructuras determinan a los individuos o los individuos a las estructuras, lo mejor es adoptar una postura intermedia, tomando en cuenta tanto el asunto de la pertenencia a un orden social como el carácter generativo, cambiante y múltiple de la cotidianidad. Como diría Giddens ${ }^{5}$ con su concepto de "dualidad de la estructura”, la cual hace referencia a la distinción entre la acción y la estructura, como elementos contrapuestos; "la dualidad de la estructura" indica cómo el nivel de lo estructurante, si bien es definido dentro de los márgenes de las determinaciones estructurales y contextuales, pone el acento en la generación de lo social a través de las prácticas cotidianas diarias. Para Giddens los sujetos tienen capacidad transformadora o agencia (agency), lo que determina la relación entre el nivel individual y el estructural, por esto indica que “...las prácticas cotidianas, la interacción situada de los individuos, influye en las propiedades de los sistemas sociales de vasta escala, donde transcurre la vida social moderna” (Giddens, 1993).

Tomando en consideración los elementos expuestos de algunos de los autores que han teorizado sobre la vida cotidiana, una definición posible para vida cotidiana sería: ${ }^{6}$ "una dinámica humana y social heterogénea, donde se transminan, enlazan o coexisten determinaciones sociales, comportamientos y vivencias culturales y psicosociales. Los cuales en su movimiento formativo dan cuenta de la historicidad de los sujetos en su vivir de todos los días” (León, 1999: 146).

\footnotetext{
${ }^{5}$ Estoy conciente de que la propuesta de Giddens es contraria a la de Bourdieu en el sentido de que el primero tiene una noción de individuo como un ser racional dotado de capacidad de acción, enfoque cercano al de los economistas neoclásicos. Bourdieu, por otro lado, es criticado por adoptar una concepción muy pasiva de los individuos quienes son determinados casi totalmente por su habitus. Considero, sin embargo, que ambos enfoques pueden ser complementarios.

${ }^{6}$ Que la autora de esta definición prefiere no adjetivar y llamar cotidianidad.
} 


\subsection{La noción de apropiación}

La vida cotidiana está relacionada con la noción misma de apropiación de ahí la segunda pregunta que me he planteado sobre ¿cómo se apropian de estas tecnologías? La apropiación es la forma en que los individuos objetivan sus condiciones sociales de existencia en lugares y tiempos determinados. La apropiación ocurre cuando el individuo configura su mundo a través de la mediación -en la vida cotidiana- de su propia conciencia o subjetividad y las otras conciencias y subjetividades, es el punto intermedio entre lo individual y lo colectivo. La apropiación es la relación que se produce entre el individuo y la realidad, la manera en que da forma a lo real a partir de las determinaciones estructurales pero también su capacidad de acción sobre éstas.

León (1999: 143) propone mirar a la apropiación como una forma heterogénea en la que los individuos se encuentran entramados en una serie de visiones del mundo, saberes y prácticas que se vincularán con aspectos subjetivos que en conjunto constituirán formas colectivas de expresión cultural. Con la noción de apropiación heterogénea se hace referencia a: “a) Las racionalidades que se amalgaman en una configuración 'politeísta de valores', lógicas y lenguajes, que pueden tener criterios de constitución diferentes. b) La vinculación y mediación de aspectos subjetivos, simbólicos y materiales, que devienen en formas colectivas de expresión cultural.” (Léon, 1999: 144)

La noción de apropiación expuesta alude a una ontología del sujeto social con capacidad de acción sobre las determinaciones sociales. Si bien para autoras marxistas como Agnes Heller, el individuo experimenta la vida cotidiana como una cuestión mecánica entre estímulo y respuesta -de la estructura sobre él- los autores mencionados antes dan pauta para ver al individuo con la posibilidad de actuar sobre estas estructuras a partir de la capacidad generativa de, por ejemplo, los procesos de percepción, del habitus, las modalidades o roles situacionales de Goffman y la doble vía de la estructura (estructura-estructuración).

Cabe señalar que el individuo en la vida cotidiana o "sujeto cotidiano" ha sido concebido de dos formas: el individuo que actúa 'sin tener conciencia de lo que hace' en la vida cotidiana, dejándose llevar por las circunstancias o situaciones que lo orillan o 
no a actuar -independientemente de su capacidad para transformar y ejercer influencia en las determinaciones estructurales- o el individuo que tiene como característica ontológica el poder hacer conciencia de lo que hace y cómo lo hace; en esta última concepción del sujeto se encontrarían, por ejemplo, Goffman y Giddens. Para Giddens los individuos son reflexivos, esto es, que siempre someten a revisión continua los aspectos de su vida social y sus relaciones materiales con la naturaleza (Giddens, 1991: 34). Sin entrar en detalle sobre las implicaciones que esta aseveración acarrea, comentaré que la reflexividad es para este autor la característica que permite el fluir mismo de la vida cotidiana.

Otra característica del individuo en la vida cotidiana es para Giddens (1991: 52) la llamada seguridad ontológica que significa que en el vivir cotidiano damos por supuestas cuestiones que se podrían derrumbar muy fácilmente, por ejemplo, lo referente a lo existencial. Todos los individuos desde los primeros años de vida tenemos una 'confianza básica' en lo que nos rodea, sobre todo, hacia aquéllas personas encargadas de nuestro cuidado; La 'confianza básica', la rutina y el hábito diarios forman parte de la aparición de un ‘yo' y de un 'mi', es decir, son el camino hacia la construcción de la identidad del yo.

Finalmente, cabe destacar que una de las tantas aportaciones de Agnes Heller al estudio de la vida cotidiana es el entender al individuo como dotado, no solamente de elementos cognitivos o intelectuales, ya que para esta autora la apropiación cotidiana también corresponde al ámbito de lo afectivo y emocional, cualidades que se han catalogado como irracionales, ya que "los sentimientos, afectos, vivencias, etc., son también procesos que pueden propiciar, engendrar o contener implicaciones activas que vuelven a un sujeto sobre si mismo.” (León, 1999: 150)

Asimismo, la noción de vida cotidiana, se relaciona con la de socialización. La socialización es la forma en que el individuo entra a formar parte de una comunidad o grupo humano a través del aprendizaje y la aculturación a lo largo de su vida. Toda experiencia individual -en la vida cotidiana- es una experiencia mediada por el proceso de socialización. La socialización define, por un lado, la forma en la que un individuo se apropia del mundo que el rodea a partir de su subjetividad, que finalmente se mezcla 
con lo grupal y el plano normativo o estructural, por otro lado, define también el cómo las estructuras normativas son llevadas a cabo en el plano individual.

Para León (1999: 71) las funciones mediadoras de la socialización son duales:

a) Una dirección de internalización de los marcos normativos socioculturales que devienen en mecanismos de control y autorregulación internos de los individuos, grupos y colectivos que los llevan a pensar, sentir y actuar de determinada manera. Un ejemplo de ello es la acepción de socialización como la adopción y apropiación de los valores, creencias, hábitos y costumbres que llevan al sujeto a insertarse en la sociedad mediante la operación de ciertos agentes como la familia, escuela, religión, etc. (...)

b) Una dirección de externalización en donde las pautas internalizadas son explicitadas y difundidas entre los miembros de un grupo para conformar verdaderas redes de comunalidad y legitimadas que dan cuerpo a la normatividad social. En este caso el movimiento central radica en el mecanismo de compartir con otros los contenidos sociales ya interiorizados y objetivados.

La noción tradicional de socialización trata de sujetos que son formados o 'socializados' por una serie de agentes, sin embargo, para Bourdieu, los sujetos son agentes ubicados y entramados en la dinámica de espacios sociales específicos que los condicionan, como la familia o la escuela. La familia es una sólida célula de identificación para los individuos y la primera instancia de socialización, en este sentido es en la llamada socialización primaria cuando el individuo aprende los significados, emociones y elementos necesarios para posteriormente llevarlos a la práctica y condicionar su socialización secundaria, la cual se llevará a cabo, sobre todo, en la escuela.

Para Bourdieu (2002: 84) "la familia y la escuela funcionan, de modo inseparable, como los lugares en que se constituyen (...) las competencias juzgadas como necesarias en un momento dado del tiempo, y como los lugares en los que se forma el precio de esas competencias, es decir, como los mercados que, mediante sus sanciones positivas o negativas, controlan el resultado, consolidando lo que es 'aceptable', quitando valor a lo que no lo es, condenando a perecer a las disposiciones desprovistas de valor.” 


\subsection{El sentido: los significados en la vida cotidiana}

Otra de las preguntas que he formulado se refiere a ¿qué sentido se atribuye a las tecnologías? El sentido tiene que ver con el cómo las prácticas cotidianas adquieren cierto significado para los individuos o cómo los individuos atribuyen ciertos significados a sus acciones diarias. Hablar de sentido corresponde a la parte simbólica de la vida cotidiana, a la "organización social del sentido, como pautas de significados” o al "conjunto de hechos simbólicos en una sociedad” (Giménez 2005). Para este autor lo simbólico recubre el "vasto conjunto de los procesos sociales de significación y comunicación" ${ }^{\text {, }}$ y este conjunto se puede desglosar en tres problemas principales:

1) La problemática de los códigos sociales (o sistemas articulatorios) que se refiere a que lo simbólico no puede ser tratado como solo una parte integrante de la vida social, sino como una dimensión que abarca todas las prácticas sociales, ya que las dimensiones simbólicas están en todas partes.

2) La problemática de la producción del sentido, de ideas, representaciones y visones del mundo, tanto en el pasado como en el presente. Esto se refiere a que el símbolo no se agota en su función de significación, sino que sigue vigente en los diferentes empleos que de éste hacen los usuarios para actuar sobre el mundo y transformarlo en función de éste a través de su interacción.

3) La problemática de la interpretación o del reconocimiento, que permite comprender a la cultura como una dimensión analítica de las prácticas sociales que manifiesta cierta autonomía y una relativa coherencia. En otras palabras, es "el interjuego de las interpretaciones consolidadas o innovadoras presentes en una determinada sociedad”, (Giménez, 2005).

\footnotetext{
${ }^{7}$ Cursivas en el original.

${ }^{8}$ Cabe mencionar también el tema del poder en este apartado ya que "las prácticas culturales se concentran, por lo general, en torno a nudos institucionales poderosos, como el Estado, las Iglesias, las corporaciones y los mass-media, que son también actores culturales dedicados a administrar y organizar sentidos. Hay que advertir que estas grandes instituciones (o Aparatos), generalmente centralizados y económicamente poderosos, no buscan la uniformidad cultural, sino sólo la administración y la organización de las diferencias, mediante operaciones tales como la hegemonización, la jerarquización, la marginalización y la exclusión de determinadas manifestaciones culturales. De este modo introducen cierto orden y, por consiguiente, cierta coherencia dentro de la pluralidad cultural que caracteriza a las sociedades modernas.” (Giménez 2005) Cursivas en el original.
} 
La problemática de la producción del sentido se conecta directamente con la distinción que hace Bourdieu (2003) entre “formas simbólicas” y estructuras mentales interiorizadas, por una parte, y símbolos objetivados bajo la forma de prácticas rituales y de objetos o artefactos cotidianos, por otra. Se trata de la diferencia que establece entre formas interiorizadas y formas objetivadas de la cultura. Estas últimas corresponden a lo observable, a lo que puede ser objeto de estudio etnográfico, como las danzas, los monumentos, la comida, etc., por otro lado, las formas simbólicas interiorizadas corresponden a los esquemas cognitivos, las ideologías, las mentalidades, actitudes, creencias y conocimientos.

Las formas simbólicas interiorizadas pueden ser comprendidas a partir de la noción de representación social de Serge Moscovici (1961) quien reformula a partir de la psicología social el concepto durkheimiano de representación colectiva. Para Durkheim (1898) las representaciones colectivas son formas de conocimiento construidas socialmente, que no se pueden explicar recurriendo a la psicología individual. Para Moscovici por su parte, las representaciones sociales no son sólo productos mentales sino que son construcciones simbólicas que se crean y se recrean en las interacciones sociales. Moscovici (1981: 181) las define como "un conjunto de conceptos, declaraciones y explicaciones originadas en la vida cotidiana, en el curso de las comunicaciones interindividuales. Equivalen, en nuestra sociedad a los mitos y sistemas de creencias de las sociedades tradicionales; puede incluso afirmarse que son la versión contemporánea del sentido común”.

Aunque el tema del sentido y los significados es mucho mas vasto y complejo, aquí sólo señalaré finalmente una nota final sobre las representaciones sociales: "las representaciones sociales no son un simple reflejo de la realidad, sino una organización significante de la misma que depende... de factores más generales como el contexto social e ideológico, el lugar de los actores sociales en la sociedad, la historia del individuo o del grupo...”, además, las representaciones sociales “son estables y móviles, rígidas y elásticas. No responden a una filosofía del consenso... permiten explicar la multiplicidad de tomas de posición individuales a partir de principios organizadores comunes” (Giménez, 2005). 


\section{Los medios de comunicación en la vida cotidiana}

Cuando se hace referencia a los “medios de comunicación” inmediatamente viene a la mente la radio, la televisión o el periódico -llamados también medios de comunicación "masiva”" - pero también un teléfono, un celular o una computadora. Al situar a los diferentes medios de comunicación en el espacio de la cotidianidad, éstos presentan una doble modalidad o doble función pues además de ser artefactos tecnológicos, también son portadores de contenidos y significados socializadores con determinaciones sociales sobre valores, actitudes y maneras de ser, esto es, son formadores de cultura ${ }^{10}$. Los medios de comunicación como artefactos tecnológicos pueden ser comprendidos desde el punto de vista de la construcción social de la tecnología, punto de vista que pone en el centro a la tecnología o artefacto y analiza los significados que se producen alrededor de ella; también se suele caer en lo que se denomina el determinismo tecnológico, es decir, el pensar en éstos como tecnologías que por sí mismos generan cambios sociales al estilo de una bala hipodérmica.

\subsection{Los medios de comunicación como artefactos tecnológicos}

Los medios de comunicación como objetos o artefactos tecnológicos son también conocidos como “tecnologías de la comunicación y de la información” (TICs) ${ }^{11}$, ya que son tecnologías cuya característica principal es la transmisión de información. Cabe señalar que esta es la denominación que en los últimos tiempos se les ha dado debido a las propiedades que presentan artefactos como la computadora o la red Internet o, incluso, los teléfonos celulares o los IPODS.

Desde la perspectiva de la teoría de la construcción social de la tecnología, basada en $L a$ construcción social de la realidad de Peter Berger y Luckmann, los medios de

\footnotetext{
${ }^{9}$ El término "masivo", referente a las masas, ya no es usado en la actualidad debido a la confusa connotación que presenta. Por un lado, hace alusión a la "sociedad de masas" de la que se hablaba a finales del siglo XIX a propósito de la Revolución Industrial y el crecimiento masivo de las ciudades. También tiene una connotación negativa al referirse a las "masas" como pasivas o inertes frente a las estructuras sociales, al estilo de la Escuela de Frankfurt. Como Thompson (1997: 46) es mejor llamar a éstos los “media” o “comunicación mediática”.

${ }^{10}$ Silverstone y Haddon (1998: 42) indican que toda tecnología tiene una doble articulación: la dimensión técnica de la máquina, del aparato como objeto con su cierto diseño e imagen y los mensajes que ésta contiene.

${ }^{11}$ Para Mayans i Panells (2002: 228) estas siglas que a veces se acompañan con el adjetivo "nuevas" presentan cierta inclinación a un determinismo tecnológico o tecnodependencia: "la validez del concepto en lo nuevo es claramente criticable. La novedad de un determinado fenómeno... tiene caducidad evidente o inminente. Lo nuevo dura poco. Y el calado del fenómeno social al que prestamos nuestra atención es mucho más profundo que algo simplemente nuevo...”
} 
comunicación como artefactos tecnológicos están construidos socialmente en el sentido de que los grupos que diseñan la tecnología, los consumidores y los intereses económicos y políticos desempeñan un papel importante en la forma final que tomará cada tecnología (Pinch y Wiebe, 1994). La teoría de la construcción social de la tecnología señala que los diferentes 'grupos sociales relevantes' asociados con el desarrollo de un artefacto tecnológico comparten un significado del artefacto - un significado que podía ser usado entonces para explicar las trayectorias particulares del desarrollo que toma el artefacto (Pinch, 1997: 26). Cuatro categorías fundamentales sustentan el constructivismo social de la tecnología:

a) La primera es la de los grupos sociales relevantes. Estos son los grupos que participan en la construcción socialmente significativa del objeto. Cada grupo social relevante para un artefacto técnico, se demarca a partir de los problemas concretos que plantea, de las distintas soluciones que propone a estos problemas, así como de los significados compartidos que atribuyen al artefacto en cuestión. (Santos y Díaz, 1997: 54)

b) La segunda categoría es la de la flexibilidad interpretativa, que se refiere a la pluralidad de interpretaciones a que está sujeto todo artefacto técnico, "una suerte de hermenéutica de la tecnología (...) De la pluralidad de interpretaciones pueden resultar aplicaciones o usos de los artefactos muy distintos a los que estaban ceñidos por una normatividad original...” (Santos y Díaz, 1997: 54).

c) La tercera categoría corresponde a los mecanismos de cierre y estabilidad de un artefacto. A pesar de la flexibilidad interpretativa y de la participación de diversos grupos sociales, en algún momento los artefactos técnicos se estabilizan. Sin embargo, al igual que los dramas sociales de Victor W. Turner, cualquier mecanismo de cierre y estabilización contiene las semillas que en el futuro reanimarán los viejos problemas o crearán otros nuevos, de aquí que esta estabilización se temporal y a veces muy frágil (Santos y Díaz, 1997: 55).

d) Una cuarta categoría que introduce Bijker es el ya mencionado "esquema tecnológico” ya que un artefacto tecnológico se va desarrollando en el contexto o limitantes de un determinado esquema tecnológico (Santos y Díaz, 1997: 55).

Por otro lado, para Silverstone y Haddon (1996) los medios de comunicación como artefactos tecnológicos son también socialmente construidos a partir del diseño y de la 
domesticación del artefacto. La fase del diseño de cualquier tecnología, en este caso cualquier medio de comunicación como una televisión, tiene tres dimensiones:

a) La creación del artefacto que consiste en su diseño del artefacto, el hacerlo funcional.

b) La construcción del usuario, fase que consiste en pensar a qué usuario van dirigidos los artefactos.

c) La captura del consumidor que consiste en reconocer la importancia de la tecnología en la cultura de consumo del capitalismo, el artefacto será objeto de consumo.

Asimismo, la domesticación del artefacto tecnológico tiene las siguientes dimensiones:

a) La comodificación, que es cuando las tecnologías emergen en el espacio público, se convierten en mercancías.

b) La apropiación que consiste en no solamente usar las tecnologías sino hacerlas familiares y parte de la esfera privada.

c) La simbolización, que son las acciones que los consumidores realizan para señalar a otros su participación en el consumo y la innovación.

Me centraré aquí en la apropiación que para Silverstone y Haddon (1996) es cuando una familia adquiere una tecnología y se da a la tarea de encontrarle un lugar en la casa, es decir, la objetiva. Además la incorpora al patrón cotidiano de la vida familiar dependiendo de las dinámicas y políticas de cada familia. Cabe señalar que cada familia tiene ciertas divisiones en cuanto al género que determinarán los usos que cada miembro haga o no de las tecnologías (Silverstone, 1992: 19). Finalmente, la apropiación da lugar a la conversión que es la que enlaza a los miembros de un hogar con el mundo público de significados compartidos, pues recordemos que la apropiación es finalmente el punto intermedio entre lo individual y lo colectivo.

Asimismo, el ver a los medios de comunicación como artefactos tecnológicos llevan a lo que se conoce como el determinismo tecnológico, es decir, a aquellas teorías sociales que ponen el acento en la tecnología como causante directa del cambio social o cultural. Se considera que los cambios sociales son producto, en gran medida, del tipo de tecnología predominante en un momento histórico dado, por ejemplo, aquellas teorías que indican que el origen y desarrollo del capitalismo se debe a los importantes avances técnicos que dieron como resultado la aparición de la máquina de vapor o de las 
poderosas máquinas tejedoras como la Spinning Jenny ${ }^{12}$. El determinismo tecnológico considera a la tecnología como variable independiente que llega a influir de manera lineal en la forma de vida de las personas.

En estudios sobre los medios de comunicación este enfoque ha sido muy influyente sobre todo por escritos provenientes de la llamada Escuela de Toronto de los años sesenta. Autores como Harold Innis, Marshall McLuhan, Walter S. Ong, Derrick de Kerckhove o David Olson consideraban que con el advenimiento de la electrónica la humanidad estaba dando un salto a una sociedad cualitativamente diferente, solo comparable al salto humano que se dio cuando se inventó la escritura y predominó sobre la oralidad. McLuhan, máximo exponente de la Escuela de Toronto, indicó que con el advenimiento de los nuevos medios de comunicación, como la televisión, y su creciente desarrollo tecnológico, la sociedad se convertiría paulatinamente en una “aldea global” interconectada a través de estos medios de comunicación.

En el campo de la antropología también ha tenido cabida este enfoque al tratar a la tecnología como "un proyectil que golpea ambientes culturales, sociales, políticos y económicos bien sean resistentes, ya absorbentes, o en fin más o menos deseosos de su aparición” (Santos y Díaz, 1997: 48). Sin embargo, Santos y Díaz (1997: 49) indican que la tecnología como "institución global” no ha sido del todo tratada por la antropología ya que se le ha considerado como sólo una parte de la cultura material, sobre todo, dentro de las sociedades tradicionales.

Una de las consecuencias del determinismo tecnológico - de pensar en la tecnología como determinante en los procesos sociales- es el calificar a la sociedad presente y su transformación como una "sociedad de la información”, sobre todo a partir del surgimiento de la computadora y la red Internet. Se dice que estamos ante el cambio de era: "tras la edad de las herramientas y la materia trabajada, tras la de la máquinas y la energía empleada, la edad de la cultura y de la información.” (Balandier, 1988: 173). La llamada “sociedad de la información” define el paso de una sociedad moderna industrial a otra nueva en donde la información tiene un alto peso en todas las

\footnotetext{
${ }^{12}$ Máquina hiladora inventada en Inglaterra alrededor de 1764 y que redujo la cantidad de trabajo socialmente necesario para producir hilo.
} 
actividades humanas. ${ }^{13}$ El nuevo modelo social propuesto por la sociedad de la información se caracteriza por:

-Cambio de una economía productora de bienes materiales a otra predominantemente productora de servicios.

-Expansión de las ocupaciones profesionales, científicas y técnicas.

-Expansión de los conocimientos teóricos.

-Extensión de las innovaciones tecnológicas. (Rojo, 2003: 19)

Para Castells (1999: 43) en la época industrial la principal fuente de productividad es la introducción de nuevas fuentes de energía y la descentralización de su uso durante la producción y los procesos de circulación, en el modo informacional, la fuente de productividad está en la tecnología, el procesamiento de la información y la comunicación de símbolos, pues "lo que es específico del modo de desarrollo informacional es la acción del conocimiento sobre sí mismo como principal fuente de productividad." 14

Quisiera señalar que de las posturas antes expuestas me interesa retomar la categoría de “flexibilidad interpretativa” o pluralidad de interpretaciones que toda tecnología puede tener según la postura de la construcción social de la tecnología. Asimismo, retomaré el momento de cierta estabilidad que alcanzan y que vuelven a generar nuevos significados al estilo de los dramas sociales de Victor W. Turner. Sin embargo, todo esto ocurre en un "esquema tecnológico", es decir, dentro de ciertas determinaciones estructurales que limitan la variedad de significados que éstas pueden generar. De Silverstone y Haddon (1996) tomaré el momento en el que el artefacto tecnológico se hace familiar y se

\footnotetext{
13 "La informatización introduce con el autómata un ser de tercer tipo (inserto entre el hombre y las cosas), produce un nuevo género de objeto desprovisto de su evidencia difuminando la diferencia entre lo material y lo inmaterial, y provoca un desdoblamiento de la sociedad como resultado de las conexiones y comunicaciones múltiples, aun multiplicables. Al término encontramos la hiperrealización y la desaparición de lo real conocido.” (Balandier, 1988: 173)

${ }^{14}$ Castells establece una diferencia entre “sociedad e la información” y “sociedad informacional” (Castells, 1999: 47). El término informacional "indica el atributo de una forma específica de organización social en la que la generación, el procesamiento y la transmisión de la información se convierten en las fuentes fundamentales de la productividad y el poder." Una de las críticas al determinismo tecnológico es que los cambios sociales no solamente ocurren a partir de las tecnologías sino de otros factores a nivel político, estatal o cultural. La tecnología no determina la sociedad pues la sociedad es la que dicta el curso del cambio tecnológico, a través de la iniciativa personal, la innovación tecnológica o las aplicaciones sociales, por eso señala Castells (1999: 31) que "El dilema del determinismo tecnológico es un falso problema". Asimismo, una de las críticas hacia la "sociedad de la información” la desarrolla el historiador Flichy (1984) quien argumenta que las comunicaciones se han llevado a cabo a lo largo de varios siglos y no debe pensarse en una ruptura o fragmentación de diferentes tipos de sociedades.
} 
incorpora a la vida cotidiana (no de la familia, como hacen estos autores, sino del individuo), es decir, el cómo se incorpora en un momento dado de la historia del artefacto y del individuo, y finalmente el cómo se enlaza este significado privado con los significados públicos compartidos. Finalmente, quisiera mencionar que los resultados que este trabajo genere podrán comprobar o no algunas de las ideas surgidas del determinismo tecnológico, en cuanto a, por ejemplo, la nueva estructura de la sociedad informacional, es decir, "si se trata de una verdadera revolución: si las transformaciones producidas o anunciadas por la sociedad digital constituyen el orto de una situación nueva, radicalmente distinta” (Cebrian, 2000:50).

\subsection{Los medios de comunicación como portadores de contenidos culturales}

Los medios de comunicación como portadores de significados y contenidos -demás de ser artefactos tecnológicos- pueden ser abordados desde diferentes posturas teóricas, por ejemplo, desde la influencia que éstos pueden tener en la vida de las personas, su capacidad de persuasión o desde las gratificaciones que se obtienen de sus contenidos. ${ }^{15}$ Históricamente la investigación de las audiencias ha hecho hincapié sobre todo al poder que tienen los medios como elementos constructores de realidad, ya sea con influencias a corto o a largo plazo, aunque en las últimas décadas se ha revisado este modelo y se ha hecho mención de la importancia que juegan los intereses personales, estilos de vida, motivaciones o capacidad de adquisición al momento de recibir y decodificar una comunicación mediática (Wolf, 1994: 182).

Sin mencionar a detalle cada una de las posturas que se han tomado para el análisis de las comunicaciones mediáticas comentaré, en primer lugar, que cuando se toma en cuenta al medio de comunicación como transmisor de contenidos se está haciendo alusión -desde una perspectiva semiótica- a las estructuras y mecanismos internos del texto, mensaje o programa que invitan a la audiencia a hacer ciertas lecturas preferenciales bloqueando otras, esto es, a analizar el contenido y los supuestos que subyacen en este contenido (Morley, 1996: 133). El modelo de S. Hall, por ejemplo, sobre la codificación- decodificación de los textos indica que los mensajes tienen una lectura preferencial (es decir, la lectura del texto que tiende a llevar al lector) aunque

\footnotetext{
${ }^{15}$ Ver por ejemplo a Wolf (1994)
} 
reconoce también la posibilidad de otras lecturas negociadas o de oposición de los mensajes (Morley, 1996: 53).

En segundo lugar, es importante señalar que la comunicación mediática es un fenómeno social contextualizado, esto es, que no puede comprenderse al margen de los contextos más amplios de la vida social (Thompson, 1997: 27). El significado que un individuo le de a un mensaje dependerá de las estructuras que posea para interpretarlo ya que los mensajes no pueden significar cualquier cosa y los individuos deberán reconocer algunas de las normas y convenciones de acuerdo con lo que un mensaje está produciendo para que tenga algún sentido. Como indica Thompson éstos límites son amplios y dejan un gran margen a la posibilidad de que el mensaje transmitido por un medio de comunicación pueda entenderse de manera distinta por diferentes individuos o grupos en diferentes contextos socio-históricos (Thompson, 1997: 66).

En tercer lugar, se debe tomar en consideración - desde una perspectiva antropológica- a los lectores, audiencia y espectadores, quienes imprimen a este contenido su propio sentido, no como sujetos pasivos, sino como miembros de una cultura, familia, grupo o clase social: "de ahí que el modo en que respondamos a los mensajes que nos ofrecen los medios de comunicación dependa precisamente del grado en que coincidan con otros mensajes (o se opongan a ellos), con otros puntos de vista que hayamos encontrado en otras esferas de nuestra vida diaria” (Morley, 1996: 113).

Estos dos últimos puntos remiten a la primera parte de este escrito referente a la construcción de sentido en la vida cotidiana, en otras palabras, al significado que los individuos dan a las acciones diarias como el ver la televisión en un contexto determinado.

\subsection{El caso de la red Internet: la construcción de la cultura virtual}

Los medios de comunicación como la radio o la televisión, presentan la doble modalidad de poder ser comprendidos como artefactos tecnológicos generadores de sentido debido a su forma o sus características más bien físicas, como elementos significativos de un nuevo modo de organización social, o como portadores de cultura a través de sus contenidos mediáticos. Sin embargo, según algunas investigaciones 
pioneras en la materia, la red Internet presenta una triple modalidad debido a que no sólo es un artefacto tecnológico y portadora de cultura a través de sus contenidos, sino que es constructora de una cultura nueva, una cultura online o virtual que tiene sus propias reglas o códigos.

A partir del estudio de las relaciones puramente on-line que se dan en la red Internet, las nuevas formas de socialidad, comunidades virtuales o chats, se ha llegado a conceptuar a la red Internet como una cultura con sus propias reglas, como una "tecnocultura" aparte, es decir, una cultura real operando en un espacio virtual creada a través de la comunicación mediante la interactividad (Green, 2002: XXXI). Incluso hay antropólogos como Downey, Dumit y Williams (1995 citado en Mayans 2002b) que partiendo de esta consideración han ido aún más lejos y proponen un área de investigación denominada 'Ciberantropología' cuyo centro sería solamente el estudio de las tecnologías mediáticas, especialmente la red Internet. En su manifiesto indican que esta nueva área debería centrarse en: a) la ciencia y la tecnología como actividades culturales, b) el cuestionamiento del lugar central que el ser humano ha ocupado en la antropología y mirar también hacia las máquinas y, finalmente, c) en ver a las tecnologías como productoras y reproductoras de la realidad social.

Sin embargo, hay quienes abogan por el estudio de la tecnología situada en el espacio contextual, que además de implicar un punto de partida teórico es, asimismo, una opción metodológica: partir del campo offline, de la etnografía en un territorio físico determinado, es decir, de la forma como se ha trabajado en la antropología tradicionalmente. Este grupo de investigadores indican que los fenómenos relacionados con la red Internet y en general las comunicaciones mediadas por ordenador (CMO) deben ser abordadas por la etnografía desde su realidad social y local. Daniel Miller y Don Slater (2000) dicen que el ciberespacio no puede ser tratado como una esfera separada de la actividad social y tratan de explorar la dialéctica entre la lo virtual y lo real. Wittel (2004) aunque está a favor de una etnografía multisituada y en movimiento, indica que los estudios que solo se enfocan en la red no son "etnografías” y que solamente podrán ser completadas como tales con trabajo multisituado en un sentido físico, es decir, en los cibercafés, en oficinas, en escuelas, etc. También Keith Hart (2004) indica que aunque la etnografía tradicional ignora cosas como el intercambio de negocios que solamente se hace a través de la red, Internet no es "el mundo", es un 
mundo en línea al cual todos traemos las particularidades de nuestro lugar en la sociedad offline, por lo que no puede ser satisfactorio estudiar las formas sociales de Internet independientemente de lo que la gente trae a éste desde sus vidas.

Cabe mencionar que este último punto tiene que ver con algunas preguntas formuladas en este proyecto: ¿De qué modo afecta Internet a las relaciones sociales en el tiempo y el espacio? ¿Es distinta esa organización a la de la vida real? ¿Cómo los jóvenes reconcilian lo virtual con lo real? ¿Es 'lo virtual' experimentado como algo radicalmente diferente y separado de 'lo real’? ¿Hay una frontera divisoria entre la vida online y la offline? 


\section{La modernidad como marco macro-estructural de la vida cotidiana}

Hablar de modernidad resulta un tanto complicado ya que como señala Balandier (1988: 144), "la modernidad no ha sido recibida positivamente, en general, porque no ha sido nunca concebida claramente.” Sin embargo, pienso que al mencionar algunas características de lo que se considera como la época moderna -más como constructo teórico que como realidad empírica- pueden iluminar algunas de las cuestiones que llamaré macro-estructurales que rigen la vida cotidiana en el presente, en las sociedades actuales. Asimismo, considero pertinente tomar a la teoría de la modernidad como punto de partida ya que es precisamente en este periodo -con la aparición de la imprenta- en el que surgen los medios masivos de comunicación.

La modernidad ${ }^{16}$ como concepto sociológico hace referencia a la época histórica que va desde el siglo XIX hasta nuestros días, esto es, una época que marca una ruptura con el pasado 'tradicional', antiguo o premoderno y que va de la mano con las ideas de la Ilustración, el progreso de la razón del individuo, el capitalismo, el surgimiento de las instituciones y organizaciones actuales y el surgimiento de los Estados nacionales. Aunque incluso se pueden rastrear sus orígenes en el siglo XV, para Giddens (1991: 26) el término modernidad puede ser equivalente al "mundo industrializado", es decir, a las "las relaciones sociales que lleva consigo el empleo generalizado de fuerza física y maquinaria en los procesos de producción”, en otras palabras, con el capitalismo como sistema de producción de mercancías.

Según Touraine (2006: 18) el modernismo, como ideología de la modernidad, se basaba en la idea del reemplazo del sujeto y de Dios por la ideas de la racionalización de la sociedad, la cual era causa de la ruptura de vínculos sociales, sentimientos y costumbres llamadas tradicionales. Asimismo, la ideología de la modernidad supeditaba al individuo a la sociedad a través del movimiento de la secularización: "El ser humano ya no es una criatura hecha por Dios a su imagen; es un actor social definido por los

\footnotetext{
${ }^{16}$ A diferencia de la modernidad, el modernismo alude a los estilos que asociamos a los movimientos artísticos que se iniciaron alrededor del cambio de siglo y que hasta hace poco dominaron en las distintas artes. Sus rasgos fundamentales son "la autoconciencia y reflexividad estética, rechazo a la estructura narrativa a favor de la simultaneidad y el montaje; exploración de la naturaleza paradójica, ambigua, indeterminada e incierta de la realidad." (Featherstone, 1991: 30)
} 
papeles que cumple, es decir, por la conducta asignada a su posición y que debe contribuir al buen funcionamiento del sistema social.” (Touraine, 2006: 25)

En la modernidad persisten dos mitos o discursos mayores y complementarios que rigen la vida de las representaciones o imaginarios de la época según Balandier (1988: 166): la concepción del progreso y de concepción del Apocalipsis. La modernidad se piensa como un conjunto de cambios continuos y acumulados que, gracias al dominio de la naturaleza mediante la ciencia y la tecnología, darán lugar a la elevación de las condiciones de vida y del ser humano. Por otro lado, la modernidad se piensa -desde una postura revolucionaria- como ruptura, como una serie de cambios que dan origen a discontinuidades:

Lo que así se manifiesta en acción en la modernidad presente, es un paso a los extremos: hacia el desencanto y el pesimismo radical, hacia el encantamiento y el optimismo absoluto. Las desilusiones engendran la desaparición de las esperanzas: las de la realización de un progreso continuo, la de la posibilidad de un liberalismo bien domesticado, las de la conducción de una revolución globalmente posible. Pero a la inversa, el encantamiento producido por la aceleración de los avances científicos y técnicos y su extraordinaria capacidad acumulativa conduce a predecir: 'mañana será todo posible'. Desde esta perspectiva, como en otro tiempo desde la del Renacimiento, no hay criterios de lo imposible; la fe en la razón sabia e instrumental no conoce ya la incertidumbre. Se dice en lenguajes diferentes pero recurriendo, todos, a la caución de la ciencia (Balandier, 1988: 167) ${ }^{17}$.

Por un lado, se habla de que gracias al avance de la ciencia y la tecnología el hombre será libre de la alienación, podrá ser más libre, independiente de la naturaleza y creativo. Por otro lado, estos mismos instrumentos que ha creado el hombre para la extensión de sus sentidos y cuerpos, se han vuelto contra él mismo y se han escapado de su control. Los futuros se vislumbran como un cercano Apocalipsis en donde nuevos riesgos, fragmentaciones sociales y exacerbación capitalista se realizarán.

\footnotetext{
${ }^{17}$ Cursivas del autor.
} 


\subsection{Características de la modernidad}

La modernidad tiene características muy particulares que la diferencian del llamado mundo premoderno; algunas de éstas son: a) la modernidad indica ruptura con el pasado; b) la modernidad fragmenta; c) la modernidad es universalizante; d) la modernidad es dinámica (separación del tiempo y del espacio); e) la modernidad es un proceso inacabado (ruptura y permanencia).

La modernidad al concebirse como ruptura, se caracteriza por un descrédito de los sistemas explicativos existentes acerca del devenir de la sociedad y de la cultura dando como resultado el abandono de los relatos de los orígenes, los relatos fundadores como los mitos (Balandier, 1988: 144). Los individuos en la modernidad actual son escépticos respecto a las razones providenciales, así como también, al mito fundador moderno que pone a la ciencia y a la tecnología como centro del progreso humano. Las instituciones tradicionales como la familia o las autoridades religiosas pierden valor frente a los medios de comunicación, la movilidad social y la diversificación de los estilos de vida. Los estilos de vida son las rutinas diarias que se siguen para vestir, comer, actuar y estar con los demás, incluso dan significado a quién se es frente a los demás. En situaciones de premodernidad no se puede hablar de estilos de vida ya que la vida diaria estaba marcada por el pasado y la tradición, en cambio, en la modernidad actual el individuo tiene ante sí una gran variedad de estilos de vida que puede seguir ${ }^{18}$.

En las sociedades tradicionales las relaciones sociales estaban ancladas en los lazos personales, sin embargo, en la modernidad el individuo está sometido la diversificación de las circunstancias de interacción. Los individuos pueden encontrarse con otros individuos diferentes y distantes, y cada encuentro requiere de habilidades apropiadas para cada situación. Estos encuentros diversificados se llevan a cabo sobre todo en la ciudad: espacio social privilegiado por la modernidad. La ciudad simboliza el triunfo de las libertades individuales, la separación con respecto a la sociedad tradicional y la

\footnotetext{
${ }^{18}$ Touraine (2006: 26) indica que esta división entre sociedades modernas y tradicionales "el término que define a la sociedad moderna es vago, como si solamente la sociedad llamada tradicional estuviera organizada alrededor de un principio positivamente definido $\mathrm{y}$, por lo tanto, capaz de regir dispositivos institucionales, mientras que lo que define la sociedad moderna sería negativo, fuerza de disolución del antiguo orden antes que de construcción de un orden nuevo."
} 
misma crisis producto de la modernidad que más adelante se comentará (Balandier, 1988: 170).

La modernidad, dicen algunos autores como Ulrich Beck, se caracteriza por ser "la sociedad del riesgo”, expresión que indica que en la vida social actual están presentes nuevas formas de riesgos y peligros que se deben afrontar, lo cual genera un sentimiento de incertidumbre constante en los individuos, así como también, una búsqueda constante de seguridad en sistemas como la magia, lectura de cartas o la futurología. Además, en la modernidad están presentes los estados de crisis recurrente, tanto a nivel estructural como en la vida cotidiana de los individuos. Esto genera un clima de inseguridad, fragmentación e impotencia constante en los individuos (Giddens, 1991: 243).

La modernidad, además, tiene tendencias universalizantes, esto es, que "nadie puede desentenderse de las transformaciones generadas por la modernidad (...) es un fenómeno dialéctico: el dinamismo de lo local y el acaparamiento de lo universal” (Giddens, 1991: 35). Esto significa que, incluso, las personas menos favorecidas económicamente o aquellos habitantes de países menos desarrollados y menos modernizados también son parte de la ola universalizante de lo moderno. Balandier (1988: 193) indica, por ejemplo, que un aspecto particular de la modernidad actual es la comunicación generalizada, de las sociedades y las culturas: "por primera vez en la historia, todas son comunicantes”. 19

La vida moderna es dinámica debido a dos características principales. En primer lugar, la separación del tiempo y del espacio. Mientras que en situaciones de premodernidad el tiempo y el espacio se vinculaban mediante la situación en un lugar, estaban localizados, en la modernidad, con el invento del reloj mecánico se apartó al espacio de la localización, dando lugar a muchas formas de “tiempo vivido”. El vaciamiento del tiempo y del espacio da lugar a la segunda característica: el desenclave, esto es, el cómo las relaciones sociales se extraen de contextos locales y se re-localizan en espacios temporales indefinidos ${ }^{20}$ (Giddens, 1991:29).

\footnotetext{
${ }^{19}$ Sin embargo, cabe aquí hacer la crítica de que la modernidad siempre ha sido caracterizada por las naciones occidentales desde una perspectiva más bien eurocéntrica.

${ }^{20}$ Esto da lugar a las "señales simbólicas" como el dinero. El dinero deja en suspenso el tiempo y el espacio ya que permite transacciones entre individuos que nunca se encuentran frecuentemente. Los "sistemas expertos", por otro
} 
Finalmente, como Habermas (1989) lo indicó alguna vez, la modernidad es un proyecto inacabado refiriéndose a que si bien las filosofías de la Ilustración que guían el proceso no han fracasado, están dialécticamente componiéndose y recomponiéndose. En este sentido, sin adentrarme por el momento en la significación de la propuesta de Habermas, comentaré que la modernidad es un "proceso" inacabado pues aunque la modernidad tiende a la universalización o a la fragmentación, tiene en su interior elementos contradictorios que emergen de estas mismas tendencias homogeneizantes. Mas que un estado de cosas acabado la modernidad es un proceso dialéctico en la que persiste la tradición y lo moderno, el mito del Apocalipsis y el del progreso, formas tradicionales de vida y formas modernas, artefactos tecnológicos novedosos y en continuo cambio que promueven la permanencia de rituales del pasado y la renovación de la unidad familiar.

La persistencia de tradición es también parte de la modernidad ya que el pasado no ha logrado borrarse por completo $^{21}$ : “como el anverso y el reverso de una moneda, la tradición es inseparable de la modernidad” (Balandier, 1988: 192). Margaret Mead (1997: 19) diría que "En el mismo momento en que un nativo de Nueva Guinea contempla una pila de ñames y la define como ‘un montón’ porque no sabe contar, los equipos de Cabo Kennedy calculan el segundo exacto en que una misión Apolo debe cambiar su rumbo para colocarse en órbita alrededor de la luna.”

Por último, la modernidad lleva en su seno un doble camino que conduce hacia la racionalización del sistema $\mathrm{y}$, al mismo tiempo, la creciente aparición del sujeto racional. Touraine (2006: 40) indica que la historia de la modernidad está -desde un comienzo- dividida no entre tradición versus progreso o razón, sino en los individuos defensores de la razón y de la instrumentalidad para lograr la felicidad y aquellos que quieren transformar al sujeto divino en humano a través del paradójico camino de la fe y

lado, son sistemas abstractos que también surgen en la modernidad, sistemas en los que confiamos aunque no los conocemos (debemos confiar en que sí funcionan): los médicos, las máquinas, el terapeuta etc. (Giddens, 1991: 31)

${ }^{21}$ Los cambios que ocurren en una región o clase podrían no ocurrir en otra, o podrían ocurrir de manera diferentes, a niveles y con consecuencias totalmente distintas. De aquí que resulte difícil establecer conclusiones generales sobre el cambio cultural... Sólo se necesita traer a colación el continuo debate sobre la tesis de la secularización -según la cual el desarrollo de las modernas sociedades industriales se acompaña del declive del papel y del descrédito de las creencias religiosas- para convencerse de lo difícil que resulta generalizar sobre cambios en los valores y creencias. (Thompson, 1988: 71) 
la predestinación: "Por un lado, algunos espíritus retornarán hasta el milenarismo; por otro lado, algunos descenderán al nivel de la búsqueda de una utilidad definida por los mercaderes. Pero entre estos precipicios, la historia de la modernidad será siempre el diálogo sin componendas posibles entre la racionalización y la subjetivación.” (Touranine, 2006: 44).

Esta última idea pone el acento en el individuo, en el rescate del sujeto como agente activo de la modernidad -agregaría, en la vida cotidiana- y no solamente como ente pasivo al servicio de estructuras que van más allá de su vida cotidiana: "La subjetivación es la penetración del sujeto en el individuo y por consiguiente la transformación -parcial- del individuo en sujeto (...) La subjetivación es lo contrario del sometimiento del individuo a valores trascendentes... en el mundo moderno es el hombre quien se convierte en el fundamento de los valores puesto que el principio central de la moral es la libertad...” (Touraine, 2006: 209). Este último párrafo se relaciona y complementa, por cierto, con los primeros capítulos de este escrito.

\subsection{Medios de comunicación y modernidad}

Es posible indicar que los medios de comunicación masiva son causa y consecuencia de la modernidad. El surgimiento de los medios masivos de comunicación tiene una estrecha relación con lo que se conoce con la época moderna por lo que cabe decir que son tecnologías características de la modernidad y, por lo tanto, representantes simbólicos de los valores e ideales modernos.

Hay autores que, desde una postura antropológica, argumentan que algunas de las instituciones características de la época moderna han sido resultado de las aceleradas innovaciones técnicas que han acompañado a los medios de comunicación como la imprenta. Benedict Anderson (1991) tiene como hipótesis que al surgir de imprenta y propiciar la aparición de publicaciones periódicas, se comenzaron a generar “comunidades imaginadas” que constituyeron las bases para la formación de conciencias nacionales. Los individuos comenzaron a leer los mismos textos, unificando 
poco a poco las diferentes lenguas vernáculas que existían en Europa, creando una comunidad virtual de lectores conectados a través de la imprenta. ${ }^{22}$

Las imprentas y editoriales -que surgieron a principios de la Europa moderna como instituciones culturales y económicas- contribuyeron también a la difusión del protestantismo y a la fragmentación de la cristiandad, además de promover la difusión de autores clásicos como Ovidio, Virgilio o Cicerón entre las élites urbanas y los universitarios. Los libros y otros textos se incorporaron a la vida cotidiana, que tenían carácter esencialmente oral, y de manera gradual transformaron las tradiciones y su modo de transmisión (Thompson, 1997: 89). Asimismo, el desarrollo de la imprenta dio lugar al intercambio de noticias a través de publicaciones periódicas construyendo un sentido del mundo más allá del entorno inmediato de los individuos.

Por otro lado, cabe señalar, asimismo, la tesis de Habermas, quien sostiene que el capitalismo mercantil en el siglo XVI y las cambiantes formas institucionales del poder político crearon las condiciones para que, a principios de la Europa moderna surgiera una nueva forma de esfera pública que se consolidó sobre todo en Inglaterra de principios del siglo XVII. "El reino de lo privado, pues, comprendía tanto el dominio en expansión de las relaciones económicas como la esfera íntima de las relaciones personales, cada vez más desvinculada de la actividad económica y anclada en la institución de la familia conyugal” (Thompson, 1997: 101).

Thompson (1998: 72) indica, desde una perspectiva sociológica, que con el advenimiento de las sociedades modernas a finales de la Edad Media y principios del periodo moderno, tuvo lugar una transformación cultural sistemática. Gracias a las innovaciones técnicas asociadas con la impresión y posteriormente, con la codificación electrónica de la información, se produjeron, reprodujeron y pusieron en circulación formas simbólicas a una escala sin precedentes, originando, a partir del siglo XV, lo que denomina la "mediatización de la cultura” debido a los cambios en la manera en que los seres humanos comenzaron a comunicarse. Giddens (1991: 38), por su parte, lo

\footnotetext{
${ }^{22}$ Aunque esta hipótesis tiene varias críticas, por ejemplo, Thompson (1997: 92) indica que la naturaleza precisa de la vinculación entre el desarrollo de la imprenta y el crecimiento del nacionalismo no ha sido comprobada a detalle. Además de que si bien en el siglo XVI había ya una comunidad de lectores, ¿cuál es el origen de los nacionalismos de los siglos XIX y XX?
} 
denomina "la mediatización de la experiencia”. ${ }^{23}$ Mientras que en la época premoderna el conocimiento del mundo se obtenía principalmente en un momento presente y localizado, a través de relaciones cara a cara con familiares y miembros cercanos de la comunidad, el conocimiento en la modernidad, a partir de la creación de la imprenta y, sobre todo, de los acelerados avances técnicos del siglo XIX, se puede obtener de fuentes deslocalizadas y atemporales.

Se dice que los medios de comunicación han originado una serie de cambios en las vidas individuales, cambios que se convierten en estilos propios de la modernidad. En primer lugar han generado una diferente percepción en el tiempo y en el espacio, ya que los individuos pueden comunicarse con otros individuos sin la necesidad de estar presentes en el mismo lugar, situación que no podía darse antes de la aparición de técnicas que hicieran posible este tipo de interacción. Pero más que la deslocalización de las situaciones comunicativas éstas se han hecho simultáneas aunque emisor y receptor se encuentren en diferentes espacios. Los medios de comunicación reducen las distancias y modifican la percepción del tiempo, dando lugar a un conocimiento de lo ajeno pero deslocalizado: "por el efecto de la difusión masiva se instaura un régimen de ubicuidad” (Balandier, 1988: 211) ${ }^{24}$.

Asimismo, con la difusión de las técnicas de la información, de la comunicación y de la imagen, aparece una forma de red más específica de la modernidad, una red que disocia a las personas con las que uno se relaciona. Esta está inserta en "el artificio, la mediación instrumental en el campo de lo social; lo transforma e incluso, lo subvierte. Cualquiera puede utilizar máscaras, asumir distintos roles, simular, conectarse alternativamente en distintas redes, presentarse bajo una identidad exterior tan cambiante como camaleón...” (Balandier, 1988: 216).

También el desarrollo de los medios de comunicación ha dado lugar, de esta manera, a lo que podríamos describir como una "historicidad mediática", esto es, nuestra percepción del pasado y nuestra percepción de las maneras en que el pasado afecta a nuestra vida actual dependen cada vez más de una creciente reserva de formas

\footnotetext{
${ }^{23}$ Aunque puede decirse que toda experiencia es mediada a través del lenguaje, la experiencia en el mundo moderno se caracteriza porque ésta está estructurada a través de la intervención de artefactos tecnológicos.

24 “El tiempo es aprehendido en el instante y el inacabamiento" (Balandier, 1988: 145).
} 
simbólicas mediáticas” (Thompson, 1988: 55). Esto significa que si bien en las sociedades premodernas la historia se comunicaba a través de la familia mediante los relatos orales con la difusión de técnicas de la información, de la comunicación y de la imagen nuestro conocimiento de la historia está dada a través de estos medios y símbolos compartidos.

Además, el desarrollo de la comunicación mediática también ha afectado al sentimiento de pertenencia de algunos individuos, es decir, a su sentimiento de pertenecer a un grupo o comunidad. El sentido de pertenencia deriva, en cierta medida, del sentimiento de compartir una historia y un lugar común, una trayectoria común en el tiempo y en el espacio. Sin embargo, Thompson (1997: 57) indica que "en la medida en que nuestro sentido del pasado dependa cada vez más de las formas simbólicas mediáticas, y nuestro sentido del mundo y nuestro lugar en él se alimenten cada vez más de los productos mediáticos tanto más se verá alterado nuestro sentido de pertenencia a grupos y comunidades”. Como antes se mencionó, la modernidad se caracteriza por un declive de la tradición y, a su vez, este declive se relaciona con los medios de comunicación. El desarrollo de los medios de comunicación facilita el declive de la autoridad y de los fundamentos de la tradición, además de que logran separar la transmisión de la tradición del hecho de compartir un espacio común (Thompson, 1997: 247).

Quisiera señalar aquí que la red Internet, como medio de comunicación moderno o como tecnología moderna tiene, como artefacto tecnológico una serie de representaciones que lo asocian con los valores antes descritos de lo moderno, es decir, con cierto “marco tecnológico” en el que prevalecen representaciones de la red Internet relacionadas con la fragmentación, la ruptura con el pasado o el doble imaginario del progreso y Apocalipsis. De esta forma el hablar de modernidad como un marco límite o estructural corresponde al intento de contestar la pregunta de cuáles son las determinaciones estructurales -si es que las hay- que se presentan en esta relación joven-tecnología, presentada al principio de este documento. 


\subsection{Los jóvenes}

Iniciaré este apartado diciendo con Cebrián (2000: 50) que "hoy el PC abandera un movimiento revolucionario y como casi siempre en estos casos son los jóvenes quienes lo encabezan”, además como bien señala este estudioso de las nuevas tecnologías, hace algunos años en Europa PC significaba “Partido Comunista” hoy en día cualquier joven sabe que las siglas se refieren a la computadora personal. También mencionaré a Balandier (1988:206) cuando indica que "las sociedades jóvenes, en su diversidad y sus variaciones, son el blanco de pruebas de la modernidad.” Así como una computadora o la televisión son tecnologías modernas, también lo que se conoce como la realidad social de "la juventud" aparece como ícono de la modernidad.

La “juventud” es un concepto difícil de definir ya que, en primer lugar, más que ser una etapa biológica de la vida de todos los individuos es una construcción cultural que varía según el contexto histórico y cultural, e incluso el contexto situacional y de clase social: "La juventud es una condición social y cultural con cualidades específicas que se expresan de varias maneras. La juventud no tiene la misma duración en el campo que en la ciudad, en la burguesía que en los sectores populares, en las sociedades modernas que en las tradicionales” (De Garay 2004: 15). En segundo lugar, la noción de "juventud” abarca tal diversidad como son los estudiantes, bandas, punks, milenairstas, empresarios, ravers, desempleados, etc. (Reguillo 2000: 20).

Aunque en la historia de la humanidad han existido diferentes formas y tipos de jóvenes y de lo que se concibe como “juventud”, se ha acordado que la construcción de la juventud como en la actualidad la conocemos es reciente, producto de la situación social de la posguerra en la que la esperanza de vida aumenta y, como resultado, la inserción de jóvenes en el mercado productivo se pospone (Reguillo 2000: 22). Todo esto aunado a la creación de una industria cultural que comenzó a ver en la juventud un blanco perfecto para la manutención de las grandes marcas a través de la construcción de consumidores y no de productos (Klein, 2000).

En cuanto a los estudios de se han realizado sobre jóvenes en México De Garay (2004: 18-19) indica que hasta mediados de los años ochenta del siglo XX éstos tocaban temas sobre salud, farmacodependencia, empleo, política, comportamiento electoral, valores y 
actitudes. Después de esa primera etapa, en la segunda mitad de la década de los ochenta investigadores como Jorge García Robles, Fabricio León, Alejandro Alarcón, Pablo Gaytán, Francisco Gómez Jara, Fernando Villafuerte, Rossana Reguillo, Héctor Castillo, Maritza Arteaga y José Manuel Valenzuela comienzan a investigar los espacios de sociabilidad y prácticas sociales que generan agregaciones juveniles específicas, particularmente las llamadas bandas, sobre todo desde la perspectiva de los estudios culturales. Finalmente, en la década de los noventa los temas se consolidan y diversifican pasando por el rock, el uso de la radio y la televisión, la violencia, la política, el uso de la tecnología, convirtiéndose en referentes para teorías como los usos y las gratificaciones y las significaciones sociales de y para los jóvenes (Reguillo, 2000: 33).

Para Reguillo (2000: 38) a pesar de la gran diversidad de los jóvenes en cuanto a clase social, género, ideología, etc., éstos comparten las siguientes características en la actualidad, dados los escenarios de globalización, triunfo del neoliberalismo y mundialización de medios de comunicación y tecnologías, características -agregaría- de lo moderno:

1. Poseen una conciencia planetaria, globalizada, que puede considerarse como una vocación internacionalista. Nada de lo que pasa en el mundo les es ajeno, se mantienen conectados a través de complejas redes de interacción y de consumo.

2. Priorizan los pequeños espacios de la vida cotidiana como trincheras para impulsar la transformación global.

3. Existe un respeto, casi religioso por el individuo que se convierte en el centro de las prácticas. Puede decirse que la escala es individuo-mundo y que el grupo de pares ya no es un fin en sí mismo, sino una mediación que debe respetar la heterogeneidad.

4. Selección cuidadosa de causas sociales en las que se involucran.

5. El barrio o el territorio han dejado de ser el epicentro del mundo.

Los jóvenes, desde su aparición como grupo visible, han estado bajo la lupa de los estudiosos por su característica de ser los culturalmente rebeldes o por representar quizás, el cambio hacia una sociedad mejor. Resulta interesante avocarse al estudio y a la relación existente entre estos dos fenómenos contemporáneos lo “tecnológico” y lo “joven” en una época en la que, en ocasiones, parecen ser sinónimos. 
Quisiera señalar que el grupo de jóvenes con los que yo estoy trabajando tienen características especiales que los hacen diferentes a otros sectores juveniles. En primer lugar, son universitarios, es decir, comprenden una minoría de hombres y mujeres que han podido llegar a la educación superior, digamos que son jóvenes “integrados”; más aún, un grupo de éstos son estudiantes en una universidad privada lo que los hace tener una serie de privilegios de los que no goza la mayoría de la población en México por ejemplo el poder viajar durante sus vacaciones, tener -en su mayoría- auto propio y residencias equipadas con agua, luz y artefactos tecnológicos novedosos. A estos jóvenes universitarios los he llamado tecno-letrados ya que a diferencia de muchos otros jóvenes de su edad, éstos tienen el capital cultural y social necesario para poder manejar y acceder a todo tipo de artefacto tecnológico, como una computadora, la Internet, un I-Pod, minicomponentes, celulares, etc. Retomando el tema de la brecha digital, estos jóvenes universitarios están del lado de la brecha de aquellos “conectados” diría García Canclini (2004), por lo que son, insisto, una minoría. 


\section{Aproximaciones al campo}

Desde la antropología, hay dos caminos metodológicos para abordar el fenómeno del uso y apropiación de la computadora y la red Internet. La primera se realiza a partir de las relaciones puramente on-line, como se ha hecho ya en algunas investigaciones pioneras con la utilización de la etnografía virtual, tomando en cuenta, entre otras cosas, las nuevas formas de socialidad que se dan en la red, comunidades virtuales o chats. La segunda forma parte del campo offline, de la etnografía en un territorio físico determinado, es decir, de la forma como se ha trabajado en la antropología tradicionalmente.

En un principio, he partido de esta última postura, es decir, de la etnografía del lugar offline. Inicié el trabajo de campo 'formal' con la observación de los jóvenes en la universidad, sus lugares de reunión y diversión y, en la medida de lo posible, en sus casas, con su familia, mediante pláticas informales. A partir de las pláticas informales elaboré una guía de entrevistas que ha sido aplicada a aquellos jóvenes que por ciertas circunstancias han estado cerca de mi y, a partir de aquí, he iniciado un juego de captación en red para alcanzar a aquellos otros jóvenes que en un principio no estaban a mi alcance. Los criterios de selección de los jóvenes entrevistados, con la finalidad de tener una muestra más o menos homogénea, han sido los siguientes:

a) Tener acceso a la computadora y a la red Internet. Ya sea en sus casas o en la escuela estos jóvenes son parte de la minoría de usuarios que actualmente en México tienen acceso frecuente a estas tecnologías de la comunicación y que, como antes mencioné, he llamado jóvenes tecno-lectrados, es decir, que cuentan con el capital cultural mínimo para usar una computadora y acceder a Internet, actividades que realizan con frecuencia en su vida cotidiana.

b) Ser estudiantes universitarios. Esto quiere decir que todos son jóvenes integrados que comparten ciertas características como el acceso a la educación superior, el mismo nivel educativo y cierto nivel cultural compartido. Al ser la mayoría estudiantes de la carrera de ciencias de la comunicación y diseño industrial son jóvenes que están posiblemente más cercanos que otros universitarios a los medios de comunicación y a la reflexión crítica sobre los mismos. 
c) Son jóvenes urbanitas. Todos habitan en la Ciudad de México o área conurbada, lo que los hacer compartir ciertas características de lo urbano como la facilidad y el acceso a los medios y tecnologías de la comunicación, acceso a la variedad cultural, servicios y oportunidades que ofrece una ciudad, acostumbrados a las grandes distancias y al uso constante de medios de transporte, etc.

d) Finalmente, quiero señalar que los he seleccionado por la cercanía y el acceso que tengo hacia ellos debido al lugar en el que me encuentro laborando y a las redes que tengo en el resto de las universidades y que me han permitido tener acceso a ellos. El primer grupo corresponde a jóvenes estudiantes de una universidad privada, el segundo, que funge en este caso como grupo comparativo es un grupo de jóvenes de una universidad pública.

Sin embargo, en un segundo momento, las observaciones también deberán incluir el entorno o contexto en línea: las interacciones que éstos tienen en la computadora y en la red Internet, las páginas y espacios que visitan, no como una cultura aparte, sino como una extensión de la vida cotidiana de los jóvenes. Además de la etnografía tradicional, he debido aprender a navegar como ellos lo hacen, convivir en sus comunidades virtuales y tratar de comprender desde adentro, los usos y la apropiación de la red Internet.

\subsection{Jóvenes estudiantes de una universidad privada}

El grupo de jóvenes entrevistados y observados son estudiantes de los primeros semestres de la carrera de ciencias de la comunicación y de diseño industrial en una universidad privada. En total se realizaron doce entrevistas a profundidad, un grupo de discusión y diarios personales con seis de ellos, además de tres entrevistas enfocadas con sus familiares. Estos jóvenes viven con sus familias en áreas residenciales de la zona conurbada de la Ciudad de México. Sus familias, en el sentido restringido de familia como grupo doméstico 'simple ${ }^{, 25}$, están compuestas por la célula conyugal (papá y mamá) y los hijos e hijas, no más de tres hijos en cada caso. En sus viviendas

\footnotetext{
${ }^{25}$ Los grupos domésticos 'simples' que corresponden a la familia, a nuestra célula familiar contemporánea: están compuestos ya sea del padre, la madre y de los hijos, o ya sea de un viudo o de una viuda con sus hijos, excluyendo cualquier otro pariente (Segalen, 1981: 43).
} 
cuentan con todos los servicios y tecnologías para el funcionamiento del hogar. Así describe una joven su vivienda:

Mi casa está ubicada en Vergel de Arboledas. Para llegar a ésta, se debe de entrar por los arcos que se encuentran en Arboledas, son de color marrón y están en la entrada de una avenida muy transitada llamada Santa Bárbara, que después se divide con otro nombre, San Diego de los Padres, la avenida es muy larga y hay casas de los dos lados, estas casas son bastante grandes, además cuenta con una gran cantidad de árboles y especialmente en una zona, la del Club de Golf "La Hacienda”, hay una fuente, bastante pasto y un río, esto del lado derecho, si lo vemos en sentido de Arboledas hacia mi casa; cuando hay sol, a la orilla del río se ven aves blancas (...) Mi casa cuenta con patio y jardín, una cocina la cual tiene un microondas, televisión, estufa, lavavajillas, un ante comedor y alacena. También tiene comedor, sala, cantina, gimnasio, cuarto de lavado, en el primer piso, y en el segundo piso una pequeña sala, cuatro recámaras, tres de ellas cuentan con televisión y dos de ellas con baño propio. En la parte de afuera, hay una pequeña bodega y la recámara de la persona de servicio... (Viridiana, entrevista 16 de marzo de 2006.)

En cuanto a tecnologías de la comunicación y de la información (TICs), según la clasificación de Sonia Livingstone (2002) las familias de estos jóvenes son familias 'ricas en medios de comunicación'. La clasificación de los grupos domésticos que hace esta autora es la siguiente:

a) Ricos en medios de comunicación (Media rich).- Tienen un amplio rango de viejos y nuevos medios de comunicación, más que el promedio de los grupos domésticos o familias, los miembros de estas familias tienen para escoger entre libros, computadoras personales, Internet, teléfonos, teletexto, cable o televisión por satélite, juegos de video, teléfonos celulares y walkman.

b) Tradicionales (Traditional).- Tienen en su hogar la mayoría de los medios de comunicación y tecnologías de la información excepto los más nuevos. Esto se debe, según la autora de esta clasificación, a que los hijos en estas familias son aún niños pequeños por lo que "para aquellos con suficientes recursos económicos, la 
construcción de un hogar rico en medios de comunicación o tradicional, es cuestión de elección” (2002: 42).

c) Pobres en medios de comunicación (Media poor).- Debido a restricciones financieras tienen pocos medios de comunicación y libros.

Cada uno de estos jóvenes tiene a su alcance todo tipo de tecnologías de la comunicación y de la información, ya que en sus recámaras cuentan con televisión, teléfono, mini-componentes, radios e incluso una Lap-Top para uso personal. Por esto último los he llamado jóvenes tecno-letrados, ricos en medios de comunicación y con la instrucción o capital cultural para poder usarlos. Cuando son varios hermanos jóvenes en la casa, cada uno cuenta con su propia computadora:

Yo tenía una (computadora) y estaba la de escritorio y nos peleábamos mi hermano y yo por ella, entonces mi mamá decidió darme la suya y ya cuando mi hermano entró al Tec le compró una. (Viridiana, entrevista 16 de marzo de 2006)

Las familias de los jóvenes son de clase media-alta ascendente ya que una generación atrás, los papás y mamás de estos jóvenes no tenían esta posición, se ubicaban más bien en clases medias o clases medias-bajas. Esto se observa en que sus familias han tenido una visible ruptura con aquéllos familiares (tíos, abuelos, primos) que se quedaron en la posición anterior. En todas estas familias observadas los padres y los hijos mantienen contacto más cercano con aquella parte de la parentela que mantuvo su trayectoria social -en términos de Bourdieu- de manera ascendente:

(Con la familia de mi mamá) como que al inicio estuvimos muy alejados de ellos y como que poco a poco nos integraron y yo empecé a darme cuenta de la forma de vida que llevaban y dije: ‘¡Ay! ¿No será un insulto para ellos que venga vestida así? Y cada vez que voy tengo que vestirme diferente (...) es como tipo vecindad, es una casa con varios cuartos donde viven los hermanos de mi mamá, y si, tienen una televisión, una videocasetera, un DVD y siempre que quieren consultar algo pues nos llaman a nosotros (...) De hecho somos las primeras que vamos a tener una carrera (...) De chiquitos éramos mas unidos entre primos, 
jugábamos y todo. Ahorita ya con los estudios como que se abrió más la brecha porque ellos dejaron de estudiar y decimos 'bueno ¿y ahora qué?’... (Rocío, entrevista 14 de marzo de 2006)

(Mi papá) nació en Ciudad del Carmen Campeche, tiene dos hermanos, sin embargo, la diferencia de edad es grande y eso ha impedido una verdadera relación de hermandad. Durante su niñez siempre vivió de una manera muy humilde, tenía muy poco acceso a la televisión o al radio. Estudió la primaria y la secundaria en su pueblo natal, sin embargo, en la preparatoria se mudó a la ciudad de México a vivir a la casa de su hermano Arturo; muchas veces (mi papá) ha mencionado que esta fue la etapa más triste de su vida, sufría de maltratos por parte de su propio hermano, tenía poco acceso a los medios de comunicación y tenía muchos problemas para poder estudiar... (Héctor, entrevista 17 de marzo de 2006)

Los papás y mamás de estos jóvenes tienen estudios de licenciatura concluida o trunca, se dedican a trabajar de tiempo completo en puestos directivos, jefaturas o en sus propios negocios para poder mantener su posición social y, sobre todo, poder pagar las altas colegiaturas de la universidad de sus hijos. Durante la semana los jóvenes casi no tienen contacto con sus papás y mamás, solamente por la mañana cuando se van a trabajar y por la noche cuando llegan de trabajar, a veces también los fines de semana. Una joven lo comenta así:

Viridiana: Yo no salgo mucho con mis papás, entonces si salgo me voy con mis abuelitos o mis tíos o mis primos con los que más me junto, y ya nos vamos a algún lado.

Entrevistadora: ¿Tus papás no salen contigo o tu hermano?

Viridiana: No, son esclavos del trabajo.

(Viridiana, entrevista 16 de marzo de 2006)

Parece ser que esta resulta ser una característica recurrente en las familias de esta etapa que he llamado modernidad, familias en las que ambos padres salen a trabajar y los jóvenes generalmente pasan el día solos, en compañía de amigos, sus hermanos o de la servidumbre. 


\subsubsection{Acceso a la computadora: mamás y papás ponen la tecnología a su alcance}

Los jóvenes de este primer grupo de observación tuvieron acceso a la computadora desde niños, la mayoría de ellos en la primaria. El primer contacto con la computadora fue debido a que sus papás o mamás en el contexto laboral las utilizaban y, por lo mismo, las llevaban a la casa en donde los jóvenes, aún niños podían usarla. Si tomamos en cuenta que en México el uso de la computadora y la red Internet comienza a extenderse a partir del año de 1996, las familias de estos jóvenes se podrían considerar como familias de 'innovadores' o 'aceptadores tempranos ${ }^{\text {,26 }}$, es decir, de las primeras que adoptaron esta tecnología en sus hogares. Los jóvenes de este grupo tienen en su familia, en el capital cultural que la familia les ha dado, sus primeras bases para incorporar esta tecnología como parte de su vida cotidiana. Desde muy pequeños la computadora y la red Internet formaron parte de su contexto material.

Entrevistadora: Cuéntame tus recuerdos de la primera vez que tuvieron computadora.

Viridiana: Pues yo me acuerdo la primerita en la oficina de mi mamá, tenía máquina de escribir y luego computadora, yo creo que fue de las primeras que tuvo, yo me acuerdo que la computadora era la base de todo.

Entrevistadora: ¿Y tu primer contacto con la computadora como fue?

Viridiana: En la escuela yo creo, en la escuela o en mi casa, mi mamá siempre nos llevó la computadora a la casa, pero yo creo que fue en la escuela. (Vidiriana, entrevista 16 de marzo de 2006)

Entrevistadora: La primera vez que llevaron una computadora a tu casa ¿te acuerdas cuando fue?

Héctor: Mmm, mi papá trabajaba en el IFE como en el 92. Llevó una computadora donde tú usabas los discos grandotes negros, todavía usaba MS-DOS y le ponías Win para usar Windows.

\footnotetext{
${ }^{26}$ Siguiendo las aportaciones del sociólogo Gabriel Tarde quien desde finales del siglo XIX advirtió que el ritmo de adopción de las innovaciones tiende a seguir una curva en forma de "S", la difusión de una innovación se divide en las siguientes fases o tipos ideales: a) Innovadores, b) aceptadores tempranos, c) mayoría temprana, d) mayoría tardía y e) remisos, que se han usado como tipos ideales para explicar una vasta gama de comportamientos con respecto a la innovación (Glick, 2000: 163).
} 
Entrevistadora: ¿cuántos años tenías?

Héctor: Yo tenía 6 años. (Héctor, entrevista 17 de marzo de 2006)

Entrevistadora: ¿Cómo fue aquel día cuando adquirieron la computadora en tu casa?

Rocío: Fue como por el 97 y la compramos porque sabíamos que en secundaria empezaron a introducir trabajos, imágenes, presentaciones Power Point, y mi papá dijo que ya era hora de traer la computadora. Teníamos una que mi tía nos prestó y se la devolvimos pues ya no la íbamos a volver a usar y después entré al Tec y fue cuando decidieron comprarla, pero después como a mi me pedían tener computadora aparte para hacer las prácticas, nos hicimos de la Lap. (Rocío, entrevista 14 de marzo de 2006)

Incluso los papás y mamás se jactan y muestran orgullo de poder haber puesto la computadora al alcance de sus hijos y de que éstos desde pequeños supieran utilizarla. Cabe recordar que la mayoría de estos papás y mamás no tuvieron de niños o jóvenes estas oportunidades y tratan de dar a sus hijos todo lo mejor.

Mamá: Desde que se vino el boom de las computadoras, siempre ha habido computadora aquí y hemos estado constantemente actualizándola y ellos han estado siempre en ese ritmo, viendo lo mas novedoso, una de la razones por las que se cambiaron de escuela es porque en la escuela en donde estaban tenían computadoras 286 en donde todavía tenían que usar comandos y David nos dijo que ellos no querían estudiar la historia de la computación sino mas bien estar actualizados y entonces se cambiaron a la otra en donde ya estaban con Internet y mucho mas actualizadas...

Papá: ...y tenía yo mi computadora y tenía que darles acceso a ellos, entonces los dos mayorcitos no tenían problema, hacían lo que querían hacer. A Héctor le decían el investigador submarino y a veces llegaba y mi disco duro estaba en blanco (risas). (Familia Argente, entrevista 17 agosto 2006). 
Los papás y mamás muestran orgullo de haber tenido y de tener la visión, además del capital económico, para dotar a sus hijos de la tecnología que requieren para triunfar y ser más competentes. Aquí persiste la idea de la tecnología concebida como progreso que dará lugar a mejores condiciones de vida de los seres humanos, representación persistente en la modernidad. La computadora está presente en la narrativa familiar como un artefacto necesario para mantener la trayectoria ascendente de cada uno de sus miembros.

\subsubsection{Acceso a la computadora: gracias a la red social}

En algunos casos es un amigo (red social) de la familia o pariente quien introduce, directa o indirectamente a la familia y a sus miembros en el uso de la computadora. Esto se debe, posiblemente, al medio social en el que se desenvuelven:

...unos amigos de la familia se fueron a vivir a Tijuana, entonces empezaron a vender todas sus cosas y le vendieron a mi papá una computadora super barata y como Ricardo y yo desde chiquitos tuvimos contacto con la computadora en la escuela que íbamos (...) entonces ya sabíamos usarla y mi mamá dijo 'pues bueno hay que comprárselas' y en ese entonces estaba muy de moda el Encarta y todo eso y lo usábamos para hacer tareas... (Cinthia, entrevista 15 de marzo de 2006)

A mi tío desde siempre le encantan las computadoras, el cuñado de mi papá, y entonces nos decía que ya nos compráramos una computadora, y mis papás dijeron pues si, entonces mi tío armó una y la llevó ahí a mi casa y le enseñó a mi mamá cómo se usa y todo eso. Nosotros ni la usábamos ni nos llamaba la atención, tenía unos juegos pero nunca jugábamos con ella, y a mi mamá no le gustaba tampoco pero mi tío le decía que podía hacer tarjetas de navidad y presentaciones y todo eso y pues ya le empezó a gustar y se metió a cursos de Corel Draw... (Deni, entrevista 23 de marzo de 2006)

Aunque los discursos sobre la modernidad indican la desaparición de la tradición y los lazos familiares, es aún en el seno familiar y a través de sus relaciones cotidianas con 
parientes o amigos en el que estos individuos adquieren sus primeras habilidades en el manejo de la computadora y la red Internet: “como el anverso y el reverso de una moneda, la tradición es inseparable de la modernidad” (Balandier, 1988: 192).

La familia, a pesar de los discursos que pregonan su desaparición o fragmentación, sigue siendo una sólida célula de identificación para los individuos y la primera instancia de socialización, por lo tanto de adquisición del habitus. En este sentido es en la socialización primaria cuando el individuo aprende los significados, emociones y elementos necesarios (habitus primario) para posteriormente llevarlos a la práctica y condicionar su socialización secundaria. Cabe señalar que toda familia retoma y reinterpreta del sistema simbólico que prevalece una porción y la reinterpreta, esto es la ideología familiar "un subsistema cultural que se encarga de las creencias y valores compartidos por un sistema social. Incluye explicaciones de quién y cómo somos, de dónde venimos, qué hacemos o debiéramos hacer y cómo nos relacionamos con los otros. En este sistema lo real no está separado de lo deseable pues se encuentra entreverado lo que es y lo que debiera ser” (Adler, 1993: 212). ${ }^{27}$

Un factor determinante para el uso y apropiación de una tecnología es la subcultura a la que pertenece el individuo (capital social), es decir, su red social, sus 'pares' diría Boudieu. Murdock et al. (1995 en Livigstone, 2002: 67) señala el papel crucial que juegan las redes sociales en promover alguna nueva práctica sustantiva y en mantener su uso: el saber como comprar la máquina adecuada, como renovar el software, el modelar expectativas exageradas con respecto a la computadora, etc. tiene que ver con el capital social que un individuo posee.

\subsubsection{La computadora: el papel de la escuela como mediadora}

La mayoría, aunque no todos, tuvieron un acercamiento más formal a la computadora debido a las escuelas donde estudiaban y en las que les daban clases de computación o les exigían -debido a las tareas escolares- el tener computadora. También tuvieron la

\footnotetext{
${ }^{27}$ Por cierto que ésta se asemeja a la noción de “flexibilidad interpretativa” de la teoría de la construcción social de la realidad la cual indica que los significados radicalmente diferentes de un artefacto pueden ser identificados por los distintos grupos sociales, por ejemplo, la bicicleta de rueda alta pudo fue interpretada como la máquina macho para los hombres jóvenes, fuertes y vigorosos, pero para la gente mayor y las mujeres era la "máquina insegura.” Existía una flexibilidad interpretativa sobre el artefacto, pues se le podían dar dos significados radicalmente diferentes dependiendo del grupo social relevante (Pinch, 1997: 27).
} 
oportunidad de ir a cursos particulares de computación en algunos casos. La apropiación, en su etapa de incorporación, tuvo que ver en un principio con la escuela.

Uso la computadora desde la secundaria que nos dejaban trabajos. Con eso del Encarta como que fue un 'boom' para hacer trabajos en las escuelas, mis maestros me regañaban por usarlo pero yo si lo usaba. (Deni, entrevista 23 de marzo de 2006)

Estuve en una primaria de gobierno y me pasé a una particular, cuando llegué a la particular era computación de casi tres horas, tuve que ir a regularización para que me explicaran. En secundaria estuve en una de gobierno y luego cuando vieron que me quedé aquí (en esta universidad) me dijeron 'si vas a necesitar mucho la computadora' y me metí a una clase, yo era la única niña, y llegó un momento en que yo daba la clase! (Rocío, entrevista 17 de febrero de 2006)

La escuela, juega un papel predominante en el uso de estas tecnologías o, por lo menos, así se percibe. Los jóvenes de este primer grupo, estudiantes de una universidad privada en la que el uso de la computadora y la red Internet es fundamental y es, incluso, obligatorio ven como sus amigos o hermanos que no estudian ahí están más atrasados que ellos en el uso de la tecnología.

Deni: (Mi hermana) si sabe usar la computadora y todo pero como que no le gusta mucho. Ella antes de entrar al Tec estuvo en una vocacional y ahí como que no les pedían mucho el uso de computadora e Internet, ya que hay mucha gente que no tiene acceso a éstos medios y pues realmente no la ocupó mucho, y yo si aquí en el Tec pues desde el principio para ; todo todo todo la computadora! yo creo que por eso ella está mas distante a esto (...)

Entrevistadora: ¿Cuántos contactos tienes en el Messenger?

Deni. ;Ah quien sabe! pero si muchos. Tengo un grupo como de 20 que no he acomodado en ninguna carpeta, luego tengo uno que dice amigos como unos 50 y otra carpeta que dice 'otros' y debo tener como unos 30 o algo 
así, pero realmente no es de que hable con todos y muchos ya no se ni quiénes son.

Entrevistadora: ¿Tu hermana también tiene muchos contactos en el Messenger como tu?

Deni: No, mi hermana tiene bien poquitos sus amigas de la escuela nada más. (Deni, entrevista 23 de marzo de 2006)

Como indicaría Bourdieu (2002: 84) "La familia y la escuela funcionan, de modo inseparable, como los lugares en que se constituyen, por el propio uso, las competencias juzgadas como necesarias en un momento dado del tiempo, y como los lugares en los que se forma el precio de esas competencias, es decir, como los mercados que, mediante sus sanciones positivas o negativas, controlan el resultado, consolidando lo que es 'aceptable', quitando valor a lo que no lo es, condenando a perecer a las disposiciones desprovistas de valor, cosas poco serias que 'caen como una losa'...” La escuela como transmisora de contenidos y valores está legitimada en este primer grupo, se tiene la concepción de que gracias a la escuela -la escuela privada- tienen mejores conocimientos, sobre todo tecnológicos, que otros jóvenes.

\subsubsection{Primer contacto con la red Internet: carácter lúdico}

Por otro lado, la red Internet tuvo que ver en un inicio con la expectativa que generaba el poder usarla, con un carácter más bien lúdico y de ningún modo relacionado con lo escolar. Todos tienen sus primeros recuerdos de Internet en los chats que comenzaron a usar cuando niños o en la secundaria, en el famoso (para ellos) ICQ. La mayoría recuerda el uso del ICQ y su “boom” en la prepa: Estabamos los que teníamos ICQ y los que no tenían -comentó Erandy- era la moda, todos se conectaban en la noche para platicar tonterías.

Inicias en la adolescencia, como para jugar así, para iniciarte así, pero después lo dejabas de utilizar porque dices ¿para qué? me aburre fuchi. Pero en algún momento, no sé, cuando empezaba a tener Internet o a jugar con la computadora entrabas a los chats y así, cosas así, entonces se marca como un momento que después se abandona. (Deni, entrevista grupal 17 de febrero de 2006) 
También fue -y sigue siendo- importante la Internet como una forma de estar en contacto con familiares, primos y tíos que están lejos, nuevamente indicando la solidez de la célula familiar aún en la época de la modernidad:

Entrevistadora: ¿Qué te gustaba de Internet cuando empezaste a usarla?

Cinthia: No sé, tener un mail era bien divertido, sobre todo porque tengo tíos en Monterrey, en Tabasco y en Guadalajara, entonces así como que por teléfono nunca puedo hablar con mis primos y ya teniendo un mail me comunicaba más con ellos y eso era lo que más me atraía. (Cinthia, entrevista 15 de marzo de 2006)

Además, cabe señalar que es en el aprendizaje informal, con sus amigos, con sus pares, en el que aprenden la mayoría de las cosas que utilizan (sobre todo con respecto a la red Internet), en lo que Bourdieu llamaría "la cultura libre ilegítima” que son “conocimientos acumulados por el autodidacta o de la 'experiencia' adquirida en la práctica y mediante la práctica, pero fuera del control de la institución específicamente encargada de inculcar estos conocimientos...” (2003: 22)

Pues me metía (a Internet) y me gustaba ver imágenes de las películas, después de eso también la música, me di cuenta de que podía bajar música y dije ¡ay que padre!, después leer periódicos, revistas, y lo último que conocí pues fue el Messenger. Al principio yo ni siquiera tenía una cuenta, nada más tenía la de AOL ya en cuarto semestre y no sabía cómo se sacaba una cuenta y ya una amiga me dijo que me metiera a esta página y ya la saqué en Hotmail. (Rocío, entrevista 14 de marzo de 2006)

La red Internet y su carácter lúdico con el que inician estos jóvenes en la adolescencia persiste, sin embargo hoy, como universitarios, la computadora y la red Internet también son vistos como instrumentos indispensables para el trabajo, algo de lo que ya no pueden prescindir. 


\subsection{Un grupo comparativo: jóvenes estudiantes de una universidad pública}

Como grupo comparativo incluiré algunos datos de campo obtenidos a partir de jóvenes estudiantes de las carreras de diseño gráfico, comunicación y sociología de una universidad pública. En total se realizaron cinco entrevistas a profundidad y conversaciones informales con algunos jóvenes de este grupo de observación. Este grupo de jóvenes también viven con sus familias, sin embargo, estas familias -según los casos que se han presentado y que aún no se pueden generalizar- son tanto grupos domésticos nucleares como extensos ${ }^{28}$, ya que viven, en algunos casos, con tíos, abuelos o algún otro familiar además de con sus papás o mamás.

Yo vivo en casa de mis abuelitos, somos yo, mi mamá, mis dos abuelitos, mi tía y su hija de 7 años (...) mi hermana vive con mi papá... (Jaime, entrevista 28 de abril de 2006).

$\mathrm{Al}$ igual que el otro grupo de jóvenes en sus viviendas cuentan con todos los servicios y tecnologías para el funcionamiento del hogar, aunque éste suele ser de dimensiones más pequeñas, casas medianas o departamentos. También se les puede considerar en cierto sentido familias 'ricas en medios de comunicación' ya que aunque no tienen tecnologías en abundancia o lo último que sale a la venta -como el primer grupo- tienen lo que todo joven estudiante universitario necesita: una computadora y sólo en algunos casos, módem para conexión a Internet pero no más, no tienen, por ejemplo, varias computadoras PCs o Lap Tops para cada miembro de la familia ni tampoco elementos tecnológicos tan nuevos como un I-Pod o incluso teléfono celular, como comentaron Adriana y Rebeca:

Hay unos (compañeros) que ni computadora tienen, y tienen que ir al café Internet a hacer sus trabajos y diferentes cosas, y creemos que todo mundo tiene computadora pero no es cierto... (Adriana, entrevista 19 de septiembre 2006).

\footnotetext{
${ }^{28}$ Compuestos además de miembros de la familia simple, por parientes ascendentes, descendentes o colaterales (Segalen, 1981:43).
} 


\section{Entrevistadora: ¿Desde cuando tienes celular?}

Rebeca: Yo sólo tengo como un año con él. (Rebeca, entrevista 19 de septiembre de 2006).

El tener sólo una computadora en la casa provoca que, cuando son varios hermanos estudiantes en el hogar, se generen pleitos o discusiones por el uso de ésta. Esto último se resuelve organizando el horario de trabajo para cada hermano o hermana o asistiendo, uno de ellos, a un café Internet.

Adriana: En mi casa que somos tres hermanos y cada uno estudia, de repente yo llego a las 8 de la noche iy la están ocupando! y entonces no me puedo quedar mas tarde porque tengo que hacer otras cosas y no puedo disponer de su tiempo y pues entonces ya llego aquí temprano a hacer la tarea.

Entrevistadora: ¿Cuantos años tienen tus hermanos?

Adriana: El más grande tiene 24 y el otro 19.

Entrevistadora: ¿Y siempre la están usando?

Adriana: Si, constantemente. (Adriana, entrevista 19 de septiembre 2006).

Entrevistadora: ¿Hay conflictos familiares por el uso de la computadora? Isaac: Si, especialmente con mi hermana ¿no? Por ejemplo, yo estoy acá en la computadora viendo algo y llega “necesito usarla” y pues le digo “yo la prendí primero", no pues que "te doy tanto tiempo”, no pues que “por qué” y pues ya uno cede pero así como que peleas, peleas, pues no, solamente una fricción y ya... (Isaac, entrevista 5 de enero de 2006).

Las familias de estos jóvenes son de clase media, condición que aparentemente ha prevalecido desde una generación atrás ya que los papás y mamás también solían pertenecer a este estrato social o, más aún, parece ser que han descendido económicamente en los últimos años pues algunos de estos jóvenes, aunque estudian actualmente en una universidad pública, tuvieron la oportunidad de asistir a una escuela primaria privada (por lo menos durante los primeros años). Los papás y mamás también trabajan ambos todo el día o gran parte del día pero en puestos medios, oficinistas, profesores, secretarias o empleados en general, algunos son profesionistas truncos, 
ninguno de ellos comerciante. Algunos de estos jóvenes hoy en día deben trabajar también ya sea para ayudar con los gastos de su casa o para poder mantener "sus propios gastos":

Adriana: ...si le meto mucho dinero al celular, ahí si se gasta más (que en Internet).

Entrevistadora: ¿No te regañan tus papás?

Adriana: No porque yo lo mantengo.

Entrevistadora: ¿Tú trabajas?

Adriana: Si

Entrevistadora: ¿En dónde trabajas?

Adriana: Trabajo los fines de semana en un lugar por mi casa (risas)... es que trabajo con judíos (...)

Entrevistadora: ¿Y si puedes estudiar y trabajar, no te genera algún problema?

Adriana: Pues el tiempo, de repente me veo muy atareada y pues lo tengo que hacer (...) de 11 a 7 de la noche.

Entrevistadora: ¿Es por gusto o por necesidad?

Adriana: Al principio lo hacía por gusto pero luego se volvió necesidad por la carrera que me exige lo libros y la comida y todo eso... (Adriana, entrevista 19 de septiembre 2006).

Nuevamente se observa la distancia que existe entre padres e hijos debido a que los primeros tienen la necesidad de salir a trabajar todos los días, durante todo el día. Sin embargo, al no ser comerciantes o dueños de sus propios negocios, como en el primer caso, suelen tener algunos días libres, sobre todo los fines de semana.

\subsubsection{Acceso a la computadora: mamás y papás lo consideran un gasto fuerte}

Los papás y mamás de estos jóvenes ven a la computadora y a la red Internet como algo quizás necesario, pero que implica un gasto fuerte que se debe realizar pensándolo muy bien; incluso sus primeras computadoras las pudieron adquirir gracias a un préstamo, con el aguinaldo o con algún ahorro destinado a tal gasto. Sin embargo, llega un momento en que los papás o mamás creen que se gastará menos si se compra la 
computadora pues así los hijos ya no tendrán que estar haciendo sus tareas en los cafés Internet.

Entrevistadora: ¿Cómo fue el día en el que adquirieron su computadora? Isaac: Fue en Office Depot, fuimos yo mi mamá, mi abuelita y mi hermana. Primero la vimos, checamos cómo estaba el precio, sus funciones, la memoria y después fuimos a pedirle a un tío, mi tío Marco que nos prestara para sacarla de una vez. Y ya nos prestó y la sacamos bien, la conectamos y con un CD empezamos a instalarle Windows. (Isaac, entrevista 5 de enero de 2006).

Cuando compramos la computadora fue porque los niños empezaron a aprender y me di cuenta que muchas de las tareas teníamos que ir a los cafés Internet a sacar muchas tareas, sexto, primero de secundaria, muchas tareas que era más rápido buscarlas en Internet porque no teníamos toda la información aquí en la casa (...) Gastábamos como 20 o 30 pesos dependiendo (...) Pues ya como yo también empecé a quererme superar y a tomar cursos pues pensé que ya mejor era conectarlo. Sale peor que vayan no sabemos ni donde están, estamos gastando, mejor aquí en casa y a la hora que tu quieras. (Sonia, madre de un joven, entrevista 6 de enero de 2006).

Cuando se incorpora al hogar, el gasto que implica sobre todo el uso de la red Internet sigue siendo un tema que genera problemas entre los papás y mamás que quieren ahorrar y los hijos jóvenes que “desperdician llamadas en el Internet”.

Entrevistadora: ¿Cómo ven sus mamás y papás el uso de la computadora y la Internet?

Adriana: Pues lo ven como un gasto.

Entrevistadora: ¿Un gasto? ¿Por qué?

Adriana: Es que en mi caso es de estar haciendo llamadas y llamadas para conectarse y no solo cobraban la llamada sino el tiempo y además es un lujo ¿no? el tener Internet en tu casa. No cualquiera puede tener 
Internet en su casa pero tampoco nosotras podemos prescindir de él...

(Adriana, entrevista 19 septiembre 2006).

A diferencia del primer grupo de observación es evidente que la condición social limita en cierta forma la adquisición y el uso de la tecnología. Aunque también tienen la posibilidad del acceso y éste es “imprescindible” su contacto inicial tiene que ver con un universo simbólico de limitación, de la negociación entre padres e hijos y de la connotación de “desperdicio” que mamás y papás le atribuyen, en ocasiones, a este uso. Me tocó presenciar una discusión entre un papá y su hijo universitario por tener todo el día prendida la computadora gastando luz "sin estarla usando", el joven me explicó que sus papás no entendían que la tenía que tener prendida para "bajar programas” que tardaban mucho y que incluso luego llegaba y ya se la habían apagado, por lo que tenía que empezar otra vez a bajar este programa "les voy a poner un letrerito para que entiendan”, comentó.

\subsubsection{Acceso a la computadora: a través de la red de amigos y familiares}

En estos casos la red social tuvo mayor presencia que la escuela en los primeros contactos que tuvieron con la computadora y la red Internet. Cuando niños tuvieron su primer contacto con éstas tecnologías a través de la visita a casas de amigos o parientes, también por la escuela si es que tuvieron la oportunidad de tener alguna clase de computación. Sin embargo, su contacto fue sobre todo en los años de la secundaria, tiempo después que los jóvenes del primer grupo.

Entrevistadora: ¿Cual sería el primer recuerdo que tienes de la computadora?

Jair: Una que tenía el Windows 3.11

Entrevistadora: ¿En tu casa?

Jair: No, en casa de un amigo, y la veía y decía ¡wow!

Entrevistadora: ¿Cuantos años tenías?

Jair: Como unos 13.

Entrevistadora: ¿Y quién te enseñó a usar la computadora?

Jair: Pues viendo nada más, ya después empezaba yo a agarrarle y todo...

(Jair, entrevista 29 de abril de 2006). 
El primer encuentro que tuve fue en clases de computación, y me acuerdo que la primera vez que entramos a Internet que para mi era así como que no le prestaba atención, así como “¿qué padre no?”. Pero yo creo que lo primero que vimos fue como páginas de carácter académico. (Adriana, entrevista 19 de septiembre 2006).

En estos casos las escuelas primarias o secundarias en las que estudiaron, al parecer no tuvieron un papel significativo en el uso de estas tecnologías. Este grupo de jóvenes más bien aprendió por su cuenta o con ayuda de amigos o familiares. Debido a los pocos cursos de computación o contacto formal que tuvieron con la computadora -y que tienen actualmente en la universidad- se sienten poco diestros en cuanto a tecnología, presentan un sentimiento de inferioridad tecnológica frente a jóvenes de otras universidades, más tecnológicas. Esto último lo pude notar cuando, al saber que también entrevistaría a jóvenes de otras universidades, preguntaban si ellos eran "mejores” o “sabían más” sobre computadoras. Cabe señalar que los jóvenes del primer grupo analizado, estudiantes de una universidad privada en la que el uso de la computadora y la red Internet es fundamental y es, incluso, obligatorio, ven cómo sus amigos o hermanos que no estudian ahí están más atrasados que ellos en el uso de la tecnología.

Entrevistadora: ¿Cómo te sientes en cuanto a uso de la tecnología?

Adriana: Creo que si nos falta mayor preparación para el uso tecnológico a futuro...

Entrevistadora: ¿Los profesores no les inculcan de alguna forma el uso de la computadora, plataformas, etc.?

Adriana: No, no mucho, algunos te dicen que necesitas sacar tu correo.

Entrevista: ¿No todos tienen correo?

Adriana: No, cuando llegamos a la carrera muchos ni siquiera sabían como sacar su correo y tenías que decirles cómo... (Adriana, entrevista 19 de septiembre 2006). 
Entrevistadora: ¿Te consideras hábil en el uso de la computadora?

Jaime: Yo creo que si me falta, he aprendido muchas cosas en la escuela y

por mi parte pero aún así hay muchas cosas que están fuera de mi

comprendimiento. (Jaime, entrevista 28 de abril de 2006).

Mi percepción desde el punto de vista de una observadora externa es que tanto los jóvenes del primer grupo como los del segundo grupo tenían prácticamente los mismos conocimientos en materia de computación, sin embargo, es relevante el dato del sentimiento de "inferioridad tecnológica” de éstos últimos, ¿por qué si los usos son similares, unos creen saber más y otros creen saber menos? Esto posiblemente tiene que ver con la representación social que existe sobre los jóvenes de universidades privadas como tecnológicamente más competentes que otros.

\subsubsection{Primer contacto con la red Internet: la red "pirata"}

Es interesante que este grupo de jóvenes tuviera su primera conexión a la Internet de manera "pirata”, ya sea porque alguien les pasó una clave o se conectaron a algún servidor de manera clandestina. Las historias de la primera conexión pirata abundan, incluso cuentan cómo algún amigo con clave a la red les pasaba su clave a todos los demás hasta que eran tantos los que la usaban que ya era inutilizable. La necesidad de conectarse y estar al día ocasionó en muchos casos que la habilidad y la creatividad de estos jóvenes imperaran sobre el nulo acceso que podían tener. Hay quienes aún, en estos momentos, recurren a las claves piratas para conectarse a la red.

Entrevistadora: ¿Cómo fue que por primera vez se conectaron Internet?

Isaac: Teníamos uno pirata que vino a poner mi primo Javier pero como tenía muchas fallas, entonces ya después el vecino fue el que vino y nos dijo "yo te puedo conectar el Internet" y se subió a todos los departamentos...

Entrevistadora: ¿El le conectó a todos los departamentos?

Isaac: Si, el se subió a informar y nosotros le dijimos "si, ¿cómo está la onda?”. Lo que pasa que él tiene Prodigy y entonces lo que hizo fue en un MODEM conectar cables y pasarlos ahora si que a cada departamento en 
este edificio. Él paga su Internet con la cuota de algunos departamentos y

aparte gana dinero... iqué inteligente!... (Isaac, entrevista 5 de enero 2006).

Entrevistadora: ¿Qué tipo de conexión a Internet tienes?

Rebeca: El de la banda ancha.

Entrevistadora: ¿De qué marca o compañía?

Rebeca: No se (risas)... Es que yo tengo una clave de la SEP y con esa me

conecto.

Entrevistadora: ¿Y de donde la sacaste?

Rebeca: Nos la regaló el papá de una amiga de mi hermana. (Rebeca, entrevista 19 de septiembre 2006).

Aquí se deja ver el sujeto activo con respecto al sistema, es decir, la posibilidad de actuación a partir de los elementos que el entorno le ofrece y de incorporación de prácticas que ya son imprescindibles no por las vías que “oficiales” que se le ofrecen, sino mediante las vías alternativas para no pagar más o economizar en lo más posible el gasto que implica la Internet. Recordemos que para Giddens los individuos son reflexivos, esto es, que siempre someten a revisión continua los aspectos de su vida social y sus relaciones materiales con la naturaleza para poder actuar (Giddens 1991: 34).

\subsection{Apropiación de la computadora y la red Internet en la vida cotidiana}

La vida cotidiana es el vivir ordinario de todos los días. La vida cotidiana como punto de partida se refiere al nivel "micro" de la sociedad en la que se produce y se reproduce ésta, al cómo los jóvenes -en este caso- se apropian de artefactos tecnológicos como son la computadora y la red Internet para reproducir algunas de las estructuras y significados de la modernidad, pero también para generar significados opuestos o diferentes. El cómo a través de la apropiación los jóvenes se afirman como sujetos activos -con agencia, diría Giddens- frente al homogéneo avance de la modernidad que se presenta como una totalidad, como una estructura o forma social a veces independiente y con vida propia. 
A pesar de las diferencias que existen entre ambos grupos a partir de las historias de sus familias, la escuela, su primer contacto con la computadora y la Internet, y más allá de su diferenciado capital económico -que no se debe minimizar-, estos jóvenes pertenecientes a una misma generación tienen más similitudes de lo que ellos mismos perciben, muy posiblemente por el hecho de ser todos universitarios y urbanitas, y más aún, por vivir en una misma época que he teorizado como la modernidad y que se interioriza en sus estilos de vida, en las connotaciones generalizadas de la tecnología que tienen o no a su alcance y del mismo significado del "ser joven" en la actualidad. En otras palabras, si bien estructuras como la historia familiar o el capital económico tienen que ver con el cómo los jóvenes usan y se apropian de la tecnología, este uso y apropiación se llega a deslindar de estas determinaciones y adquiere cierta independencia, la cual llega a ser la conformación de una "cultura juvenil” o "cultura tecnológica” propia de este grupo y momento histórico preciso, es decir, de una generación.

\subsubsection{Anclaje en la vida offline}

Si bien se dice que en la modernidad las relaciones sociales se han deslocalizado, éstas siguen guardando relación con los referentes premodernos como generadores de sentido. La mayor parte de los usos que los jóvenes hacen de estas tecnologías están anclados -por lo menos en este grupo de análisis- en la vida real o en la vida offline. Ninguno de ellos mantiene relaciones en la red si éstas no tienen una relación con su vida cotidiana, con su escuela, trabajo, amistades, novio, personalidad, identidad, etc. Cuando se hacen amistades en la red, tarde o temprano, se resuelven, se continúan o se dejan en la vida offline. En los casos estudiados, la simbolización o acciones para ser visibles ante los otros - según el modelo de Silverstone y Haddon (1996)- se realizan en la vida cotidiana y no la vida en línea.

Entrevistadora: ¿Has conocido a alguien a través de la red?

Cinthia: Si un niño, pero es que fue muy extraño porque por Messenger me aparecía la ventanita de que me había agregado alguien y dije ;ay! pues quien sabe quién es, y le di aceptar y ni yo lo conocía ni el me conocía porque a él también le salió la ventanita de que yo lo había agregado, quién sabe como pasó eso y nos fuimos conociendo y resultó 
que nuestras mamás se conocen, fueron compañeras de trabajo hace muchos años y nosotros ya nos conocíamos de chiquititos pero pues quien sabe porqué se agregó (...) Estuvimos platicando y me enteré de que vive como a 5 minutos de mi casa y por las escuelas en las que habíamos estado nos dimos cuenta que igual y nuestras mamás se conocían, yo le pregunté a mi mamá si sabía y dice iay si! ¡si sé quien es! Y bueno ya después del Messenger nos empezamos a hablar por teléfono y ya ahorita somos amigos.

Entrevistadora: ¿Alguna vez se han visto?

Cinthia: (...) Ya después de un año de estar platicando por el Messenger y por teléfono me invitó a salir y le dije bueno que te parece si mejor vienes a mi casa y ya fue y estuvimos platicando y hasta mis papás lo vieron y todo (...) es que a mi me desesperaba mucho platicar por Messenger, cuando ya son pláticas mas largas pues dijimos no pues ya hay que hablarnos. (Cinthia, entrevista 15 de marzo de 2006)

Los jóvenes pueden encontrarse en la red con otros individuos diferentes y distantes, sin embargo, puede decirse que su seguridad ontológica radica en reducir la incertidumbre que pueden causar estos encuentros a través de un conocimiento más cercano o presencial de la otredad. El argumento anterior se justifica cuando los chats o ICQs que en un primer momento estuvieron de moda, son hoy en día obsoletos ya que los jóvenes prefieren cerrar sus círculos a través de contactos más cercanos en el Messenger o, más recientemente, en el My Space.

Mientras que la televisión es un medio de comunicación totalmente asociado al entretenimiento, la computadora y la red Internet son relacionadas (por los jóvenes universitarios) con el trabajo y la escuela pero también -en menor medida- con el entretenimiento. El correo electrónico o e-mail se utiliza para establecer contacto con amigos extranjeros o parientes, el Messenger para ponerse en contacto con amigos más cercanos, sobre todo de la misma universidad y, sobre todo, para hacer tareas en equipo:

Por el Messenger me comunico... bueno los de otro país son por mail, tengo una amiga alemana, un amigo mexicano que vive en Alemania, una de mis mejores amigas que está viviendo en Bélgica, y con ellos es por 
mail porque casi nunca coincidimos por los horarios. Por Messenger me conecto, ni siquiera para platicar con la gente, es mas bien para hacer los trabajos de equipo, preguntar si hay tarea porque a veces se me olvida y mas que nada con la gente de aquí del Tec. (Cinthia, entrevista 15 de marzo de 2006)

En las sociedades tradicionales las relaciones sociales estaban ancladas en los lazos personales, en la modernidad, también. Aunque en la modernidad el individuo está sometido la diversificación de las circunstancias de interacción siempre guarda cierta densidad en su red social, siempre mantiene relaciones con familiares, amigos y aquellas personas que son afines a él. Sin embargo, estas relaciones ya no tienen las mismas características que tenían en el pasado pues se llevan a cabo, en un principio, a través de artefactos tecnológicos como el celular o la red Internet.

\subsubsection{La red Internet constructora de identidad generacional}

El saber usar la computadora y la red Internet y saberlos utilizar "bien”, es algo que a los jóvenes les genera una identidad generacional con respecto a sus papás y mamás. Sienten orgullo de saber usar varios programas, de resolver problemas de la computadora si éstos se presentan, ven a sus papás y mamás como “iletrados” en el uso de cualquier tecnología. Aquí recuerdo lo que comenta Margaret Mead (1997:117) cuando dice que en la modernidad prevalecen la culturas prefigurativas, aquellas en la que se da una ruptura generacional pues, a diferencia de las culturas en el pasado -que llama postfigurativas- en la que los hijos y no los padres representan el futuro y el cambio: los padres tienen que aprender de los hijos y no al revés.

Mi papá necesitaba pagar los impuestos y me parece que se siente más cómodo haciéndolo en la casa, porque si necesita algo sabe que nosotras le podemos ayudar. (Deni, 27 de abril de 2006).

Si, mi mamá es maestra y a veces utiliza la computadora para hacer sus exámenes y dice que no me vaya, yo me quedo en mi cuarto para estar cerca y dice 'es que no se mueve, no se mueve', y es que pone los dos 
dedos para mover el cursor y pues ¿cómo se va a mover? (Cinthia, entrevista grupal 17 de febrero 2006).

...el otro día le llegó un estado de cuenta de Banamex para concursos, y me dice (mi mamá) 'me voy a meter a Internet' y le digo 'pues ahí está la computadora'. Como no supo me tuve que meter yo y haber 'dame tu cuenta' le digo, 'pero ¿no es peligroso?' y yo 'pues no' y dice 'pues bueno’. (Rocio, entrevista 14 de marzo de 2006).

Siempre son ellos quienes ayudan a sus progenitores en cuestiones relacionadas con la tecnología, incluso cuando se trata del uso del celular:

(En la mañana) mi mamá me preparó el licuado y me dijo que subiéndome al transporte le marcara a su celular y colgara para que no se quedara dormida. Una observación es que no sabe programar el despertador de su teléfono para no quedarse dormida. (Laura, 26 de abril de 2006)

Además, son los jóvenes quienes fungen como el punto de contacto entre sus papás o mamás y el resto de los parientes que están lejos, que viven en otra ciudad o país.

Mi mamá... si ya sabe buscar en Internet, por ejemplo tengo una tía en Tabasco, y le escribe, al principio yo le ayudaba y escribía todo lo que quería decir y luego también mis tíos van lentos y se tardan en contestar, pero mi mamá ya no usa dos dedos y puede sola pero me pregunta '¿cómo se cambia la letra?', ya usa Power Point... (Cinthia entrevista grupal 17 de febrero de 2006)

Según los jóvenes entrevistados en el primer grupo, aunque los papás y mamás no saben utilizar la computadora y la red Internet, y en general, toda tecnología, estos son consumidores de todo lo que tenga que ver con las tecnologías mediáticas:

...mi mamá llegó el otro día muy emocionada que porque había visto una televisión así grande y plana y no se qué, y yo le digo ‘itu eres parte de la mercadotecnia!', porque en El Palacio como que saben dónde poner las 
cosas para que uno las compre y entonces mi mamá la fue a comprar...

(Viridiana, entrevista 16 de marzo de 2006)

Sin embargo, una constante es el que estos mismos jóvenes se perciben como menos capacitados tecnológicamente que los aún más jóvenes: parece que siempre habrá una generación más abajo que es más diestra que uno mismo. Asimismo, el saber o no saber usar la tecnología de la computadora es una forma de distinguirse incluso entre jóvenes de diferentes carreras y hasta de diferentes escuelas. Por ejemplo, jóvenes de ciencias sociales perciben como más aptos a los ingenieros, así como los jóvenes de esta escuela se perciben como superiores tecnológicamente en comparación de otros jóvenes universitarios.

Las nuevas aplicaciones de la Internet ha ocasionado el que en este último año se ponga de moda el pertenecer a alguna comunidad de amigos como la de Hi5 o My Space; las redes en la vida cotidiana se reproducen y se extienden en la red Internet:

Entrevistadora: ¿Qué más utilizas además del Messenger?

Benjamín: Antes si era nada más platicar por el Messenger pero ahorita ya salieron otras cosas (...) El My Space... es una página de socialización que ahorita está muy de moda y esta padre porque la puedes personalizar y te entretienes mucho y te da la libertad de que pongas todo lo que quieras acerca de ti, tus fotos, videos, puedes hasta sacarlo sin límites... De hecho salió el semestre pasado, lo que pasa es que salieron muchísimas páginas de este tipo como él Hi5, y otra que se me hace muy buena muy latinoamericana que se llama Chido Güey que también está buenísima y si le buscas tantito hay como 10 o 12 más... (Benjamín, entrevista 23 de octubre 2006)

Se dice que el individuo en situación de modernidad tiene fronteras identitarias imprecisas y que las generaciones se pierden unas con otras, es decir, no hay una frontera clara entre éstas (Balandier 1988: 168), sin embargo, señalaré que la computadora y la red Internet son para los jóvenes un elemento fuerte de construcción identitaria frente a los adultos y frente a los más jóvenes. Asimismo, los grupos de amistades que se producen en la red -en las comunidades o grupos- tienen un mismo 
patrón: el contacto con aquellos considerados como semejantes en gustos musicales, literatura o personalidad.

La gente escoge como que la que más le gusta ¿no? Por ejemplo en Chido Guey nada más tengo un amigo, y que conozco personalmente creo, uno o dos, todos los demás son pura gente que conocí ahí, o sea, gente de Jalisco y de muchos otros lados (...) y como alguien dijo que esto de My Space parece concurso de popularidad porque hay personas que de verdad lo único que hacen es estar buscando y metiéndose a páginas de los demás y añadiendo enajenadamente y mandando mensajes como para que el número de la página se noten las visitas y amigos (...) Yo más bien tengo un grupo selecto (...) Hay gente que te llama la atención, por ejemplo, conocí una niña de Estados Unidos que le gusta la fotografía y es modelo y creo que ella misma se saca las fotos y es parte como gótico y extraño y me gusta, y ya le puse: 'no pues que buenas fotos'... (Benjamín, entrevista 23 de octubre 2006)

Adelantaré que posiblemente ya no es precisamente la edad la que determina a qué generación se pertenece sino -en este caso- las capacidades tecnológicas que uno pueda tener para acceder a los códigos de los jóvenes, por ejemplo, cuando mis informantes notaban que yo tenía el conocimiento de algunos sitios de moda en Internet, tendían a establecer más confianza o igualdad en la comunicación que mantenía con ellos.

\subsubsection{El tiempo (o la falta de) una constante}

Existe una notable paradoja en el uso de la computadora y de la Internet. La mayoría de los estudiantes opina que el estar en línea es una "pérdida de tiempo" pues cuando ingresan al Messenger todos sus contactos comienzan a distraerlos y a platicar por lo que no pueden concentrarse para hacer su tarea, sin embargo, no pueden dejar de usar esta tecnología. Un hábito generalizado, que se ha convertido en rutina, es el llegar a casa después de la escuela y prender la computadora inmediatamente: 
Entrevistadora: ¿Cuánto tiempo pasas en la computadora?

Viridiana: No pues, llego a mi casa, como, veo la tele un rato y ya como a las 6 de la tarde la prendo.

Entrevistadora: ¿Para qué?

Viridiana: Para hacer tarea.

Entrevistadora: ¿Y entras al Messenger?

Viridiana: Si, si entro pero entro como no conectada, ya si hay alguien por ejemplo una profesora que necesito para hacer mi tarea pues ya me conecto y la veo, pero casi no me gusta porque luego, bueno antes si me conectaba un buen pero luego me desesperaba por que me bombardeaban porque tenía un montón de contactos, y dije, no, ya no... (Viridiana, entrevista 16 de marzo de 2006)

Cuando contratamos el Internet yo me desvivía toda la tarde en el Internet, pero ya tengo más obligaciones ahora, ya no, necesito tanto que ya no tengo tiempo... (Rocío, entrevista grupal 17 de febrero 2006)

Mi hermano y yo nos la pasamos todo el día en la computadora, más él que yo. Cuando llego (de la escuela) lo primero que hago es prender la computadora (...) mi rutina normal cuando la prendo es checar mis mails, el personal de la escuela, el de mis papás. (Cinthia, entrevista 15 de marzo de 2006)

Cabe señalar que en el primer grupo de jóvenes el hablar de la falta de tiempo es una constante. Siempre tienen muchas actividades que realizar, tareas, siempre tienen prisa y comentan que "no tienen tiempo". Cuando le pregunté a Víctor cuál era un día ‘chido’ para él, dijo que aquél en el que tuviera “tiempo” de hacer lo que quisiera, sin ir a la escuela, descansar bien, comer lo que a él le gusta comer, ver la televisión y jugar juegos de video con su novia. Esto indica que cualquier situación que los saque de su rutina sobre todo escolar es vista como "perder el tiempo" y, sin embargo, el uso del Messenger es una forma de facilitar la realización de tareas pues así no se tienen que quedar en la escuela "perdiendo el tiempo" en lo que se reúnen y se ponen de acuerdo y mejor lo hacen desde su casa. Esta paradoja ha hecho que piense en la idea de que la red Internet no es más que una tecnología que no sólo es causa de continuidades en 
cuanto a la tradición, la familia, los amigos, sino promotora también de las características modernas sobre la aceleración y cambio del significado del tiempo.

Además, y para complejizar el fenómeno de la paradoja de su uso, la computadora y sobre todo la red Internet es una tecnología que les hace compañía o con la cual pasan el rato o "llenan el tiempo". Incluso, por el comentario siguiente, se puede decir que, si bien no ha ocupado el lugar de otros medios, si se ha incorporado a las prácticas cotidianas junto con otros medios de comunicación:

De 8:00 a.m a 2:00 p.m. es tiempo ocupado entre clases, paso a la cafetería a comer entre las 10 y 12 del día, voy a la biblioteca a ver qué libros hay para leer y paso por CCI para revisar la plataforma o mail de la escuela. (Rocio, 17 de abril de 2006)

A las 7:00 p.m. me encierro en mi cuarto a seguir leyendo un libro sobre el género de terror y pongo música gótica en mi Lap Top para no quedarme dormida mientras leo. (Rocío, 18 de abril de 2006).

\subsubsection{Movilidad y/o mantenimiento de la condición social}

Muy recurrente es también la relación que los jóvenes hacen del conocimiento de la computadora y de la red Internet con la posibilidad de tener mayores posibilidades de encontrar empleo en el futuro. Como dijo Daniela, estudiante de diseño: Antes el analfabetismo era el no saber leer y escribir, pero ahora el analfabetismo incluye no leer, no escribir y no saber computadoras, ni Internet entonces esto ofrece como otro nivel. ${ }^{29}$ Esto significa, por una parte, que los jóvenes están concientes del fenómeno de la brecha digital ${ }^{30}$ que se está produciendo actualmente entre los que tienen acceso y conocimiento de estas nuevas tecnologías y los que están siendo marginados, y, por otro lado, que estos jóvenes han incorporado una de las ideas más presentes en la modernidad que relaciona a la tecnología con la posibilidad de mejora en las

\footnotetext{
${ }^{29}$ Daniela, entrevista 17 octubre 2006.

${ }^{30}$ Entre los discursos sobre la "sociedad de la información”, están aquellos que han incorporado el tema de la brecha digital, el cual se refiere a que si bien las tecnologías de la comunicación y de la información están siendo utilizadas cada día por una mayor cantidad de individuos en el mundo -quienes por lo mismo tienen pleno acceso a la información y al conocimiento generado por la humanidad- existe aún una gran cantidad de individuos, sobre todo en los países subdesarrollados, que no tienen acceso a estas tecnologías.
} 
condiciones sociales de vida. Como se observó anteriormente también los papás y mamás ven en el uso de la computadora y la red Internet una forma de que sus hijos tengan mejores oportunidades en el futuro, aunque en el segundo grupo los papás y mamás hagan hincapié en el uso “mesurado” para no gastar tanto en las llamadas o en el pago de Internet.

Los jóvenes del primer grupo ingresaron a una universidad privada por el mantenimiento de cierta condición social o por la movilidad que implica el relacionarse con miembros de un estrato superior, también por la posibilidad de tener una mejor preparación en general y, sobre todo, en materia de tecnología. Los jóvenes del segundo grupo se reconocen como menos preparados tecnológicamente y -aunque en ocasiones tienen las mismas habilidades que los primeros jóvenes- sienten que deben estudiar más o tener más clases especializadas de algunos programas computacionales para en un futuro poder competir en el mercado laboral.

\subsubsection{Representación colectiva: rechazo y alabanzas hacia las nuevas tecnologías}

En los capítulos teóricos se mencionó que en la modernidad persisten dos mitos o discursos mayores y complementarios que rigen la vida de las representaciones o imaginarios de la época según Balandier (1988: 166): la concepción del progreso y de concepción del Apocalipsis, es decir, la versión optimista y la versión pesimista de la modernidad. Este tipo de discurso también se encuentra en los comentarios de los jóvenes referentes a las tecnologías de la computadora y la red Internet:

Entrevistadora: ¿Creen ustedes que es positivo o negativo (el uso del Messenger)?

Erandy: Negativo

Entrevistadora: ¿Porque?

Erandy: Porque, por decir, nosotras como no crecimos con Messenger todavía tenemos como que la necesidad de estar con las personas y las otras generaciones. Por ejemplo, yo veo a los de los primeros semestres y desde el primer semestre es mas así... y yo siento que como que entre ellos no conviven tanto como nosotras; entonces la computadora y el 
Internet como que sí nos aísla muchísimo de nuestros compañeros y amigos y de la familia. (Erandy, entrevista 12 de octubre de 2006)

\section{Entrevistadora: ¿Tienes hermanos?}

Paloma: No, soy la única, pero eso si, no me puede faltar mi computadora. De hecho, hay veces que me dice mi mamá: iya apágala! y yo: “tengo tarea”. Incluso a veces son vacaciones y mi mamá: jes que te quejas tanto todo el semestre!, pero yo tengo que prender siempre la computadora y voy haciéndome tonta y a veces incluso no estoy haciendo nada, pero ya es la necesidad de tenerla prendida y que esté ahí... (Paloma, entrevista 12 de octubre de 2006)

(Los profesores) lo satanizan, lo ven como irreal y piensan que no es una forma real de socialización porque como no puedes tocar a la persona; como que percibo esa sensación en ellos de que es algo muy virtual e irreal como que sólo está en la mente de las personas. Y como nosotros lo tenemos absorbido es algo totalmente real, cuando estás en el Messenger no estás soñando, no es telepatía, estás hablando con la persona, cuando te ponen 'hola' y aparece ahí el cuadrito es casi tan real como cuando estás aquí con la persona. (Benjamín, entrevista 23 de octubre 2006).

Los jóvenes son reflexivos en cuanto al uso prolongado de la computadora y la red Internet, incluso algunos creen que están haciendo mal en enajenarse o perder tanto el tiempo delante de la computadora, sin embargo, no lo dejan de hacer. Sienten culpa de dejar de hacer cosas por estar en el Messenger o jugando en la computadora, a veces preferirían estar haciendo otra cosa pero la pantalla los atrae; tienen que hacer tarea, por ejemplo, y ya una vez en la red comienzan a hacer otras cosas como entrar al Hi5, a alguna comunidad o grupo de amigos.

\subsubsection{La computadora, la red Internet y otros medios de comunicación}

Finalmente, el uso que los jóvenes hacen de la computadora y la red Internet en su vida diaria está inscrito en el uso cotidiano de otras tecnologías de la comunicación y de la información como el teléfono, el teléfono celular, la radio o la televisión. No se puede 
entender el uso de la computadora y de la red Internet aislado, ya que se complementa con el escuchar música, hablar por teléfono y el ver televisión:

Hora: 5:00 a.m. (Mi papá) se levanta como todos los días a tomar una taza de café y escuchar la radio, en especial el programa de Radio Red. Se le nota algo adormilado... (Rocío, 17 abril de 2006)

Mi mamá y me hermana me recogieron en casa de mis abuelitos y nos dirigimos hacia mi casa. Luego llamé a mi novio por teléfono, me tardé como una hora, es lo único que me gusta: hacer llamadas. (Laura, 17 de abril de 2006)

La televisión sigue siendo el medio de comunicación central entre los jóvenes, sobre todo en el contexto familiar, en todos los relatos de los jóvenes entrevistados y en las observaciones realizadas siempre aparece la televisión como medio de comunicación predominante y como un medio que aún sigue siendo promotor, no tanto de la unidad familiar -como se proponía en investigaciones como las de David Morley en 'Family Television’(1996)- como del ‘contacto’ familiar, ya sea para mirar televisión juntos o para discutir por el control de lo que se mira. Si bien en este grupo de jóvenes de clase media-alta cada uno tiene una televisión en su recámara y en cada familia tienen un promedio de cinco o seis televisiones en el hogar, aún es un medio de comunicación que reúne, en ocasiones, a algunos miembros de la familia:

Hoy utilicé la computadora para hacer el SONUS y el Graphos para mi clase de redacción, por cierto me desespera el maguito feo que aparece hablando en estos programas. Prendí el radio para escuchar un poco de música antes de dormir, pero decidí bajar a ver que hacían (mi mamá y hermana) y veían 'La Verdad Oculta' y no se por qué extraña razón me quedé viendo una parte de la novela, en donde salía Galilea Montijo y veía su mala actuación. (Laura, 24 de abril de 2006)

(Mis papás) Llegaron del trabajo alrededor de las 8:45 p.m., subieron a su recámara, se cambiaron por pants y se pusieron a leer por una hora y media, después mi papá salió a pasear a los perros, cuando regresó nos 
acostamos en su cama (mamá, papá y yo) a ver la TV por una hora yo me fui a mi recámara a dormir. Llegaron muy cansados de trabajar, en la noche es el único momento en el día en que pueden descansar. (Deni, 17 de abril de 2006)

Desde el momento en que estoy subiendo las escaleras puedo percibir que (mi hermana Itzia) se está peleando con Lupita (hermana menor) por la televisión. La pelea surge a causa de que ahora le toca ver lo que ella quiera porque está en el momento de su descanso, es decir, ya no está haciendo tareas. Mientras Lupita no quiere ceder porque dice que ganó primero la televisión. (Rocío, 17 de abril de 2006)

Héctor: Hay muchos radios ahí, en la recámara de mi papá. Normalmente los tres jóvenes, los tres hijos escuchamos del radio la música y mi papá es el que ve la televisión, pero de todas maneras, ¡vaya! como que no es de que ‘¡no, yo no veo tele!’ sino que mas bien cada quien la ve a sus horas, cada quien tiene su programa o si no hay nada en la radio pues prendes la tele.

Entrevistadora: Entonces, ¿cada quien ve el programa que le gusta?

Héctor: ¡Ah no! pues cuando hay algo interesante, por ejemplo, a todos los hombres de la familia nos gusta la política, si hay algún debate político nos juntamos a verlo todos, el informe de gobierno o algo así. Entrevistadora: ¿En dónde lo ven?

Héctor: En la sala de televisión que está en el cuarto de hasta arriba o en el cuarto de mis papás. El futbol o el tenis son deportes de la casa, a todos nos gusta y vemos un buen partido de la selección mexicana o de los pumas. (Entrevista, 17 de marzo de 2006)

Rebeca: En mi casa el radio es como el aparato principal y la televisión casi no la vemos pero me gusta el canal 11, me gusta mucho.

Entrevistadora: ¿Tienes televisión por cable?

Rebeca: Teníamos cable y déjame decirte que cable es inútil ¿cuántos canales hay? ¡Y no ves nada!, estas cambie y cambie y no ves nada... (Rebeca, entrevista 19 de septiembre 2006). 
En esta investigación de ha puesto el acento en el uso y apropiación de la computadora y la red Internet por parte de los jóvenes, pero no hay que olvidar que estos artefactos se encuentran inmersos en una red de tecnologías que son parte integral de la vida cotidiana, tecnologías que en algunas situaciones son incluso más importantes de la red Internet, por ejemplo, la necesidad de portar un celular o, en el primer grupo, un I-POD. Hoy en día los nuevos medios de comunicación como la computadora o la red Internet se mezclan con otros, sin desplazarlos - como a veces se suele pensar- y se incorporan a la vida cotidiana a partir de las prácticas ya existentes de ver la televisión o usar el radio o el teléfono, es lo que Livingstone (2002:89) llama el “media mix" o mezcla de medios de comunicación en la vida cotidiana. 


\section{Conclusiones}

Aunque aquí se utilizó la comparación de dos grupos de jóvenes a partir del lugar al que asisten a estudiar, quisiera señalar que el uso que éstos dan a las nuevas tecnologías como la computadora y la red Internet los une más de lo que aparentemente los separa como jóvenes de dos estratos sociales diferentes. El uso y apropiación de la computadora y la red Internet en su vida cotidiana es muy similar en ambos grupos, aunque se perciban como diferentes; podría incluso decirse que en cierta forma el uso de estos artefactos es lo que los une como grupo identitario del "ser joven" en la actualidad. Se podría hablar, por lo tanto, del constructo teórico de cultura juvenil a partir del uso, apropiación y los códigos que se generan alrededor de estos artefactos, pues todo joven universitario los comparte.

Aunque los caminos del acceso a estas tecnologías son en ambos casos diferentes, en el primer caso más como una planeación mediada de los padres y la socialización primaria en las escuelas donde estudiaron de niños y en el segundo caso más como una exigencia de estos jóvenes al necesitarlo para hacer tareas o trabajos escolares, el lugar de llegada a la computadora y a la Internet, sus usos cotidianos presentes, son muy semejantes. Tienen que ver más con una necesidad de construcción identitaria del ser joven y de diferenciarse de sus padres y profesores que con la dificultad o no de tener una conexión rápida o la mejor computadora. En un sistema en el que los jóvenes, sobre todo los universitarios, se encuentran aún subordinados a la familia, a los papás y mamás, a las exigencias escolares y a un futuro que parece incierto laboralmente -sobre todo en el contexto de nuestro país- el saber usar una computadora y acceder a la red Internet forma parte de un escape que en la vida cotidiana tiene que ver con el momento en el que los jóvenes se pueden expresar, ser ellos mismos y manifestar sus gustos, opiniones y maneras de ser, construyendo día a día códigos a veces impredecibles para el mundo de los adultos, mamás y papás, resultado de las situaciones y de las normas, posiciones y roles de los actores que ellos mismos crean y recrean -retomando a Goffman- en el momento de la interacción joven-tecnología-joven.

Sin embargo, este escape no resulta de una acción automática, mecanizada o enajenante, sino la práctica cotidiana de un ser pensante, reflexivo, y retomando a Habermas, como una acción que tiene cierto carácter emancipador. En palabras de Giddens, como la 
capacidad transformadora o agencia (agency) que tienen los sujetos en la vida cotidiana y que pueden actuar como determinantes de la estructura social moderna. Recordemos que para Giddens los individuos son reflexivos, esto es, que siempre someten a revisión continua los aspectos de su vida social y sus relaciones materiales con la naturaleza (Giddens 1991: 34), sin embargo, no quisiera idealizar esta noción y decir que todo joven se da cuenta del carácter emancipador que pueden tener sus actuaciones en la red Internet, pues aunque así lo hagan ante los ojos de un atento observador, difícilmente lo adjetivarán por sí mismos como una acción “emancipadora” o quizás “contra-cultural”.

Además, esta relación del joven con la tecnología, creadora de lo que he denominado como “cultura juvenil”, no es simplemente virtual -entendiendo aquí virtual no como parte de una pantalla o de una relación con la red, sino como una cultura que se imagina y que por lo tanto se considera como real- sino que está anclada con el mundo de su vida cotidiana llamémosle real o quizás objetivada en formas materiales concretas. Los jóvenes como cualquier usuario de la red Internet no desaparecen en la red o se fragmentan con ella, no se escapan de la realidad a partir de una personalidad esquizofrénica, están concientes de su relación con la tecnología y con la realidad, es decir, saben que eso que está ahí es finalmente una pantalla de computadora y que, en un rato, saldrán con sus amigos, irán al cine o a la escuela. No es posible idealizar el papel de la computadora y la red Internet como elementos determinantes en sus vidas ya que los jóvenes hoy como hace diez o veinte años prefieren ante todo vivir con libertad, salir los fines de semana con amigos, ir de viaje y disfrutar la vida. Para ellos el mejor día de su vida no es estar chateando o conociendo gente frente a una computadora, sino el ir de viaje, estar con sus novias o amigos o, incluso “el no hacer nada” en la vida cotidiana offline.

Situemos, asimismo, la vida cotidiana de los jóvenes en una época que se le ha denominado modernidad. Más que como una época histórica estática, opuesta al pasado premoderno, o con características muy precisas, al hablar de modernidad he tratado de indicar que muchas de las actividades cotidianas de los jóvenes y su relación con la tecnología más que ser determinadas por la tecnología en sí misma o por la trayectoria familiar o escolar, están inscritas en un contexto mucho más amplio que de una u otra manera determina la forma de apropiación cotidiana de una tecnología. Se dice que en la modernidad los individuos pueden encontrarse con otros individuos diferentes y 
distantes y esto no sólo ocurre a través de tecnologías como la red Internet, sino también en espacios como la ciudad. Con esto quiero decir que si bien la tecnología ha propiciado estos encuentros, éstos son parte de un movimiento que va mucho más allá de la red Internet. En otras palabras, el riesgo que podría representar la red Internet como elemento de desintegración familiar o por la enajenación que podría causar según algunos papás, mamás y profesores, se debe más a un momento histórico en el que la tecnología ha sido representada como elemento tanto positivo y generador, como negativo y destructor; mismas representaciones paradójicas que se emplean para otros artefactos o situaciones modernas que implican nuevos "riesgos" que aparentemente no se vivían en las sociedades tradicionales.

Otro ejemplo, de acuerdo a lo anterior, corresponde al cómo se vive el tiempo en la época moderna actual, sobre todo, el tiempo en las ciudades; este es un tiempo ya dado como una rutina, preparado para no perderlo por ningún motivo, esto se traduce también en la red Internet, la cual funge como una forma de no perder el tiempo al realizar las tareas o establecer acuerdos a partir de este medio. Sin embargo, suele ser también un escape lúdico, para socializar, hacer amigos, que representa cierto placer culpable por “estar perdiendo el tiempo”. Nuevamente dilemas no sólo del medio sino de la época actual.

A partir de lo anterior y tomando en cuenta la historia que tiene la computadora y la red Internet (ver Apéndice) en cuando a su origen como producto del sistema -como elemento de guerra necesario en un momento de guerra fría- y como producto de la creatividad de algunos académicos y estudiantes que lo representaban como un medio para la expresión individual y la libertad, se puede decir también, que este inicio contradictorio se sigue produciendo en las interacciones que los jóvenes tienen con esta tecnología, es decir, como parte de una necesidad de tener que utilizarlas para hacer tarea, para cumplir ciertas obligaciones de estudiantes, pero también como una forma de recrearse, construir identidades activas y escapar por momentos del tiempo moderno rutinario (haciéndolo también iparadójicamente!, una rutina).

Para finalizar este escrito quisiera señalar algunas cuestiones que he dejado de lado por el momento y en las cuales deberé reparar al continuar con este tema de investigación. En primer lugar, en este primer grupo de jóvenes entrevistados no he podido distinguir 
las diferencias que pudieran existir en el uso y apropiación diferenciada que hacen hombres y mujeres. En las familias de este grupo de jóvenes ambos, papá y mamá, salen diariamente a trabajar, aunque todavía son las mamás quienes participan en los roles tradicionales que socialmente se han asignado a la mujer, como organizadoras de la esfera privada, al indicar a la servidumbre lo que se debe hacer, al preparar los alimentos, al mirar más telenovelas que los papás. Al parecer los y las jóvenes de este grupo utilizan la computadora y la red Internet de igual forma en general, incluso, quien se encuentra más entusiasta con el uso de esta tecnología es una mujer y algunos varones incluso admiran a las mujeres que suelen ser más hábiles en el uso de la computadora y la red Internet:

\section{Entrevistadora: Si se te traba (la computadora) ¿cómo le haces? \\ Benjamín: Pues ahorita que tengo la computadora limpiar pues no pasa eso pero cuando se traba mi hermana es la que me ayuda. \\ Entrevistadora: ¿Por qué tu hermana? ¿La hermana mayor? \\ Benjamín: La menor, porque es muy mañosa con ese tipo de cosas como que yo lo podría resolver pero empiezo así como que a estresarme. \\ Entrevistadora: ¿Entonces ella es muy hábil para resolver problemas de la computadora?}

Benjamín: Si, de tipo técnico si. (Benajamín, entrevista 23 de octubre 2006)

En segundo lugar, quiero comentar que hasta el momento se han contestado las primeras preguntas que dieron origen a este trabajo de investigación de manera parcial, ya que hace falta aún la observación y análisis de los grupos de jóvenes faltantes, en otras palabras, ampliar la muestra elegida a través de la red social o la "bola de nieve”. Todos los casos antes expuestos son de jóvenes que tienen relativamente las mismas condiciones económicas y sociales, acuden a la misma institución educativa, estudian la misma carrera, en el mismo semestre y su formación familiar ha sido semejante. Todos son hábiles usuarios de la computadora y de la red Internet y de los principales programas que hoy en día se utilizan en la computadora, sin embargo, de este grupo solamente una joven es “entusiasta” en cuanto al uso de la computadora y la Internet, dice "no poder vivir sin ella” y "pasar todo el día en la computadora”, digamos que, en términos de cómo las audiencias captan los mensajes de televisión según Morley (1996), esta joven tiene una "lectura dominante" de este medio; otros dos del grupo, 
tendrían una lectura “negociada” quizás, ya que la computadora y la red Internet es algo muy importante en su vida, pero hay también otras cosas que tienen mayor prioridad; las últimas tres del grupo tienen más bien una lectura “crítica” u "opuesta” a esta tecnología, la usan como todos los anteriores pero critican, por ejemplo, que en su universidad todo se haga a través de la computadora y a través de numerosos "Passwords" que hacen perder el carácter humano de la institución, además de que suelen aburrirse de estar todo el tiempo en la computadora.

Aunado a lo anterior, en este estudio se ha dejado de lado, por el momento, la concepción de los medios de comunicación como portadores de significados y contenidos, es decir, la concepción de la computadora y la red Internet como portadores de símbolos. Esto quiere decir que aún no se ha tomado en cuenta el contenido de los mensajes que los jóvenes consultan, envían o reciben a través de la red Internet. El haber elegido partir metodológicamente de la vida offline hacia la vida online ha impedido hasta el realizar un análisis minucioso de las comunicaciones presentes en estos medios de comunicación, es decir, de la computadora y la red Internet como contenedores de cultura.

En tercer lugar, en este estudio he querido evitar una postura "mediacéntrica”, es decir, atribuir a la tecnología ciertos cambios en la vida social o cultural. Más bien me he querido centrar en el individuo, en una concepción de sujeto como activo ante los cambios tecnológicos. Siguiendo a Touraine (2006) Sin embargo, resulta sumamente difícil apartar la mirada del medio de comunicación o de la tecnología cuando éste es parte del objeto de estudio. Asimismo, el abordar a la modernidad como macroestructuras presenta el problema de que éste resulta ser un concepto demasiado complejo, con muchas definiciones y críticas, además de estar relacionado más con el campo de la sociología que el de la antropología. He tratado de simplificar esta noción con la finalidad de bosquejar brevemente el cómo las formas de apropiación de tecnologías como la computadora o la red Internet entran a formar parte del "tipo ideal” de la modernidad, mientras otras formas tienen que ver más con la continuidad y la permanencia de las tradiciones. Una de las ideas que surgen a partir de la reflexión de la modernidad como constructo teórico es que los medios de comunicación como componentes de modernidad no generan cambios de tajo e incluso pueden fomentar relaciones tradicionales, cambiando solamente las formas pero no la esencia de éstas. 


\section{Apéndice. La computadora y la red Internet}

En esta parte del escrito relataré la historia de este nuevo medio de comunicación o tecnología de la comunicación con la finalidad de contextualizar su aparición en una época histórica precisa, además de subrayar su origen dual: por un lado producto del contexto bélico de la postguerra y, por otro, producto de la creatividad de sujetos activos y creativos, algunos de ellos jóvenes, desde la academia. Cabe señalar que la parte correspondiente a la historia en México requiere ser re-definida debido a la poca información que existe. Se requiere de una investigación más profunda de ésta recurriendo posiblemente a entrevistas a aquellas personas que estuvieron presentes en los orígenes de este nuevo medio de comunicación.

\subsection{Historia de la computadora y la red Internet}

La computadora y la red Internet son dos artefactos tecnológicos que tienen una historia paralela que confluye recientemente cuando ambos se unen para constituir lo que conocemos como la red Internet. La simbiosis que forman una y otra tecnología es tal que a veces se hace referencia a la computadora como si ésta fuera lo mismo que la red Internet y la red Internet no se concibe sin una computadora. ${ }^{31}$ Para Hine “...Internet es (...) una serie de ordenadores capaces de comunicarse a través de su propio lenguaje, el protocolo TPC/IP. Más ampliamente, el término Internet se emplea para referirse a un conjunto de programas que habilitan determinados tipos de comunicación e intercambio de información...” (Hine, 2004: 40).

Fue en ambos lados del Atlántico cuando los avances tecnológicos en electrónica dieron lugar a la aparición de lo que hoy se conoce como la computadora y la red Internet, aunque el mayor empuje tecnológico tuvo lugar en Estados Unidos durante y después de la Segunda Guerra Mundial. La historia mas extendida cuenta que éstas nacieron en los ambientes académicos de las universidades norteamericanas -con apoyo de la agencia de investigación del Ministerio de la Defensa (Advanced Research Projects Agency,

\footnotetext{
${ }^{31}$ A esto Alan Stone le llamó en 1970 "compunications” (“infocomunicaciones”) o "el matrimonio celestial entre ordenadores (computers) -que también tenían otros matrimonios- y telecomunicaciones” (en Briggs y Burke, 2002: 299). Desde la década de los noventa se ha puesto de moda el llamar "convergencia” a la unión de varias tecnologías, sobre todo, las digitales.
} 
ARPA) $)^{32}$ - y en algunos ambientes contraculturales de ese mismo país, por individuos que eran, al mismo tiempo, inventores y usuarios de estas tecnologías. Basado en esta historia Castells (1999: 79) afirma que "si la primera Revolución industrial fue británica, la primera Revolución de la tecnología de la información fue estadounidense con una inclinación californiana.”

Las computadoras aparecieron específicamente en 1946 en la Universidad de Pensilvania en donde Mauchly y Eckert produjeron el famoso ENIAC ${ }^{33}$ (Electronic Numerical Integrator and Calculador) computadora que pesaba 30 toneladas, fue construida en módulos de metal de dos metros y medio de altura, tenía 70000 resistores y 18000 tubos de vacío y ocupaba la superficie de un gimnasio (Castells, 1999: 67). Sin embargo, a finales de los años cincuenta, las computadoras son todavía muy raras pues en el mundo solamente había 5000 unidades y éstas solo servían para hacer cálculos matemáticos programados (Flichy, 2003: 51). La primera versión comercial de las computadoras fue la UNIVAC-1, producida en 1951 por el mismo equipo que creó la ENIAC, bajo la marca Remigton Rand, y se utilizó en el proceso del censo estadounidense de 1950 (Castells, 1999: 69); Microsoft entró en la carrera comercial de computadoras en 1953 con su máquina de tubo de vacío 701 y la IBM le siguió de inmediato con su modelo $7090 .^{34}$

El transistor fue inventado en 1947 en los Laboratorios Bell de Murray Hill (Nueva Jersey) por tres físicos, Bardeen, Bratain y Shockley, sustituyendo a las válvulas que se utilizaban para las computadoras, sin embargo, su uso no se extendió sino hasta 1959 y sobre todo para utilizarlos en las “radios de transistores” (Briggs y Burke, 2002: 314). Por otro lado, el chip fue ideado por el ingeniero Gordon Teal, que trabajaba en la Texas Instruments; para 1954 esta firma ya vendía chips de silicio del tamaño de un dedo de una mano. Estos dos inventos posibilitaron el procesamiento de impulsos eléctricos en un modo binario de interrupción, dando lugar a la comunicación con y entre las

\footnotetext{
${ }^{32}$ En la época de la guerra fría, específicamente en 1965, este ministerio suministra el 23 por 100 del presupuesto total de la investigación académica, mientras que la administración civil (Nacional Research Fundation) no aporta más que el 13 por 100 (Flichy, 2003: 53).

${ }^{33}$ También los ingleses tenían una gran computadora, la Colossus que se utilizó para que Gran Bretaña y sus aliados ganaran la Segunda Guerra Mundial (Briggs y Burke, 2002: 314).

${ }^{34}$ Cabe señalar que en la historia de las computadoras la IBM (Internacional Bussiness Machines) contó con una inmensa ventaja ya que fue producto de la fusión con la Tabulating Machina Company de tarjetas perforadas fundada en 1896, la cual contaba con una cultura corporativa muy importante (Briggs y Burke, 2002: 317).
} 
máquinas. Para 1971 un chip de silicio de un sexto por un octavo de pulgada con 2,250 transistores miniatura, tenía el mismo poder que la ENIAC (Briggs y Burke, 2002: 315).

Los comienzos de la "memoria” de las computadoras se remontan a la década de 1940, aunque fue finalmente Jay Forrester, del Massachussets Institute of Technology (MIT), quien aseguró en 1953 la incorporación de la memoria magnética a los ordenadores (Briggs y Burke, 2002: 319). Más tarde, en los años sesenta, se desarrolló el grafismo para las computadoras por la ARPA. En este laboratorio se experimentó con unas estaciones de trabajo individuales conectadas a una computadora, cada una de ellas disponía de una pantalla de visualización y de varios instrumentos de diálogo: teclado alfanumérico, ratón y teclado sintonizado de cinco teclas (Flichy, 2002: 57). Asimismo, el software para las computadoras personales surgió a mediados de los años setenta por dos jóvenes que habían abandonado sus estudios en Harvard, Bill Gates y Paul Allen, quienes adaptaron el BASIC para que funcionara en la máquina de Altair en 1976. Cuando comprendieron todas sus posibilidades fundaron Microsoft, gigante del software actual. (Castells, 1999: 71). Sin embargo, tras el invento del microprocesador, los proveedores de software se multiplicaron, palabra que se comenzó a utilizar como opuesta a la de hardware que se refería a los componentes físicos de la tecnología (Briggs y Burke, 2002: 320).

Para 1976 Ed Roberts, un ingeniero que había creado una pequeña compañía de calculadoras, la MITS, en Albuquerque (Nuevo México) construyó una caja de cálculo con el nombre de Altair, la cual estaba hecha como una computadora de pequeña escala en torno a un microprocesador. Esta fue la base del diseño de la Apple I y la Apple II, la primera microcomputadora comercializada con éxito, construida en el garaje de las casas paternas por dos jóvenes que también habían abandonado los estudios: Steve Wozniak y Steve Jobs en Menlo Park, Sillicon Valley. Ésta se lanzó en 1976 con tres socios y 91000 dólares como capital; Apple Computers ya había alcanzado para 1992, 583 millones en ventas. IBM presentó, por su parte, en 1981 su versión propia de microcomputadora, la ahora famosa computadora personal o PC, difundiendo su estándar por todo el mundo (Castells, 1999: 70).

Una de las primeras ideas antecedentes de la red Internet es el llamado "tiempo compartido", es decir, la interacción entre la computadora y los hombres o "la simbiosis 
del hombre y la máquina” que podía realizarse como una de las primeras minicomputadoras (la PDF-1 de DEC). Al respecto Joseph Licklider, psico-fisiólogo que trabajaba en el Massachussets Institute of Tecnology (MIT) dirá en los años ochenta "El PDP-1 me abre nuevas perspectivas sobre la forma como los hombres podrán en el futuro colaborar con unas máquinas como éstas” (Flichy 2003: 52). ${ }^{35}$ En este sentido cabe mencionar a los informáticos del Massachussets Institute of Techology (MIT) quienes lanzan el proyecto MAC (Múltiple Access Computer) cuyo objetivo es hacer trabajar simultáneamente a un gran número de usuarios de computadora en una misma máquina (Flichy, 2003: 54). Proyectos análogos fueron también desarrollados por los fabricantes de ordenadores IBM y Control Data. Este último abrió en 1968 una red Internacional que estaba conectada a cierto número de centros de cálculo: el Cibernet (Flichy, 2003: 59).

Es en 1969 cuando el Servicio de Proyectos de Investigación Avanzada del Departamento de Defensa estadounidense (Advanced Research Projects Agency, DARPA) desarrolla la red llamada ARPANET, compuesta por pequeñas redes autónomas que no podían ser controladas desde ningún centro. Un año después de su creación, en enero de 1970, la red conectaba ya trece centros de investigación interconectados, en 1972 pasó a 43 y en 1975 a 57 (Flichy, 2003: 63). El desarrollo de ARPANET requirió de protocolos más universales, es decir de un metaprotocolo que hiciera funcionar a redes concebidas bajo principios distintos. El sistema finalmente adoptado en 1980 se compone de el Transmisión Control Protocol (TCP) que está encargado de dividir los mensajes en paquetes de salida, reconstituirlos a la llegada, detectar errores de transmisión y remitir los elementos que falten y el Internet (working) Protocol (IP) que está encargado de organizar la circulación de los paquetes, suministra a cada máquina huésped una dirección que permite organizar el envío, este nuevo protocolo $-\mathrm{y}$ no la red en sí- es lo que se llamó en un primer momento Internet $^{36}$ (Flichy, 2003: 81).

Finalmente, fue en Ginebra, en el centro europeo de Investigación Nuclear (CERN) donde se desarrolló en 1990 un sistema de documentación hipertextual, es decir la

\footnotetext{
${ }^{35}$ En ese mismo momento, sin embargo, también se piensa en la computadora como sustituta del cerebro humano, John von Newman, concibió el sistema SAGE (red de defensa antiaérea asistida por ordenador) como un instrumento inteligente autónomo al ser humano (Flichy, 2003: 52).

${ }^{36}$ Internet es una contracción de Internetwork System (Sistema de Intercomunicación de Redes).
} 
World Wide Web con su lenguaje de descripción de documentos HyperText Markup Language o HTML en la que los documentos están situados en servidores con una dirección URL. El objetivo de Tim Berners-Lee, el principal autor del proyecto, era establecer vínculos entre las informaciones descentralizadas en diferentes máquinas. El software de la WWW comenzó a circular rápidamente en Internet (Flichy, 2003: 87).

Aunque la primera tienda de computadoras se abrió en Los Angeles en julio de 1975 y un mes después apareció la primera revista informática del hogar, la Byte (Briggs y Burke, 2002: 321), es hasta 1992 y 1993 cuando la red Internet comienza a ser conocida por el gran público norteamericano. En estos años aparecen artículos sobre Internet en la revista Time, la revista Internet World y la ciber-revista Wired. Los grandes medios de comunicación comienzan a popularizar todo lo relacionado con la red Internet a tal magnitud que la revista Newsweek hace de 1995 “el año de Internet”, abriendo su número de fin de año con una frase: “Esto cambia... todo” (Flichy, 2003: 141).

Hoy en día ya se habla de que en Estados Unidos, nuevamente en el ámbito de las universidades -apoyadas por el gobierno de ese mismo país-, se está construyendo la red Internet 2, con la finalidad de obtener una mayor calidad en la información que se envía y se recibe a través de ésta, así como también mayor rapidez. Su origen se debe a la necesidad que tienen las universidades de recuperar el espacio de las red Internet pues ésta se encuentra saturada por el comercio ya que "la Internet de hoy en día ya no es una red académica, como en sus comienzos, sino que se ha convertido en una red que involucra, en gran parte, intereses comerciales y particulares. Esto la hace inapropiada para la experimentación y el estudio de nuevas herramientas en gran escala.” (Casasús, 2004). La llamada "I2" no es otra cosa más que un nuevo protocolo de la red Internet actual que tiene las siguientes características:

-Control remoto de instrumentos (telescopios, microscopios electrónicos, etc.). Los usuarios pueden manipular instrumentos a distancia, recibir respuesta inmediata y hacer observaciones en tiempo real.

-Grid (supercómputo distribuido). Como la velocidad de la red es muy grande, en vez de que algún investigador requiera una súper computadora, usa varias computadoras distribuidas en diferentes lugares para hacer cálculos en paralelo. 
-Banco de objetos distribuidos multimedia. Cada usuario de Internet sube sus objetos (imágenes, textos, videos, audios, proyectos, etc.) a su propio servidor y los buscadores buscan en ellos con gran facilidad y rapidez para lograr intercambios y compartir recursos educativos. (Martínez, s/a)

La red Internet 2 es entonces una nueva etapa del desarrollo técnico que vuelve a partir del ámbito académico y que tiene la finalidad de quedarse en éste (Velázquez et al., 2004). Se prevé que la red Internet siga como hasta hoy con un uso comercial y la red Internet 2 sea utilizada solamente para fines educativos, de colaboración científica e investigación, volver pues, a los orígenes académicos de este artefacto.

\subsection{Historia en México}

En México hay muy pocos registros históricos serios sobre la red Internet o tecnologías como la computadora. En general la literatura mexicana que toca el tema presenta historias fragmentadas, anécdotas curiosas o miradas oraculares de lo que representa esta nueva tecnología para el futuro. Como indica Oscar Robles "es muy difícil afirmar la existencia de una única e incontrovertible historia de Internet en México, pues difícilmente una persona o alguna institución dispone de los registros históricos necesarios para sustentarla.” (Robles, 2000: 3)

En México, como en Estados Unidos, las primeras conexiones fueron también experimentos académicos, llevados a cabo en los últimos años de los setenta, en conexiones temporales -a través de líneas telefónicas- que se destinaban solamente a “bajar” correos electrónicos o información de grupos de discusión. Es en junio de 1986 cuando una universidad, el Tecnológico de Monterrey, Campus Monterrey, logró conectarse a la red BITNET ${ }^{37}$ (EDUCOM) por medio de una línea conmutada hacia la Universidad de Texas en San Antonio. La velocidad de este enlace era de 2400 bps y los equipos interconectados eran máquinas IBM 4381. En 1987 la $\mathrm{UNAM}^{38}$ logró

\footnotetext{
${ }^{37}$ BITNET se desarrolló en 1981 por Ira Fuchs y Greydon Freeman, en la City University of New York (CUNY). El primer enlace de BITNET fue entre CUNY y la Universidad de Yale. BITNET era administrada en Estados Unidos por BITNET Network Information Center (BITNIC) y EDUCOM -que posteriormente adoptó el nombre de Educause--. La frase original que dio nombre a BITNET fue "Because It's There Net" y posteriormente fue adoptado el lema "Because It's Time Net". (http://en.wikipedia.org/wiki/Bitnet)

${ }^{38}$ Es en 1994 cuando fue creada RedUNAM con el fin de comercializar el servicio de conexión a Internet. RedUNAM y las redes de Conacyt y MexNet integraron la Red Nacional de Tecnología (RNT), con un enlace E1
} 
establecer conexión con BITNET a través del Tecnológico de Monterrey Campus Monterrey, aunque más tarde la UNAM obtuvo un enlace independiente a través del satélite “Morelos II". Sin embargo, es en febrero de 1989 cuando México logró establecer finalmente su primera conexión con Internet, siendo el primer país de América Latina en conectarse a la red de la NSF (Robles, 2000: 5).

De 1989 a 1993 las universidades fueron las únicas proveedoras de servicios de Internet, por lo que en ese momento se imaginó que la Internet serviría para fomentar sobre todo la circulación de información cultural y educativa. Sin embargo, cuando en 1991 se lleva a cabo la privatización de Telmex, se abrió el mercado monoplizado hasta entonces, registrándose una aceleración del desarrollo de las redes y empresas en telecomunicación como AVANTEL y AT\&T comenzaron a interesarse en los usos comerciales de la red en México (Hernández 2006). El primer proveedor comercial inició operaciones en 1991, aunque para 1997 el uso comercial de la red era aún muy reducido (Robles, 2000: 5). Es hasta el año de 1995 cuando el número de dominios destinados a fines comerciales fue mayor que el número de dominios de instituciones educativas (Islas y Guitérrez, 2006). Cabe señalar que a partir de la segunda mitad de la década de 1990 se introdujo en México la World Wide Web (WWW) (Robles, 2000: 11).

Las grandes empresas de servicios telefónicos con mayores recursos comenzaron a acaparar el mercado mexicano y, por lo tanto, fue más difícil para las pequeñas empresas incursionar en éste. Es en los años de 1994 y 1995 cuando la red Internet crece de manera comercial, debido sobre todo a la eliminación de algunas restricciones que antes impedían el desarrollo de actividades comerciales en Internet. De acuerdo a la información del Network Information Center de México (NIC México), el número de dominios "mx” apenas ascendía a 111 y la mayoría de los dominios aún correspondía a instituciones de educación superior. A finales de 1995, el total de dominios "mx" se incrementó a 326, y el número de dominios de empresas comerciales por primera vez superó al total de dominios asignados a instituciones educativas (Gutiérrez e Islas, 1998). Ya para 1999 los proveedores de Internet en México (ISP) eran principalmente

(dos megabits por segundo). El 6 de febrero de 1995 fueron publicadas las páginas WWW del periódico La Jornada, el primer diario mexicano que fincó su presencia en Internet. (Islas y Gutiérrez, 2006). 
empresas multinacionales, hecho que tuvo lugar debido, entre otras cosas, a que Telmex incursionó tarde en la red Internet (Robles, 2000: 9). Ese año se da lo que se conoce como "la guerra de los portales" cuando empresas multinacionales y nacionales se enfrentan en línea para acaparar al público de la red Internet a través de su publicidad (Robles, 2000: 9).

El gobierno mexicano se mantuvo alejado del desarrollo y fomento de la red Internet en un primer momento. Se cuenta incluso que el gobierno del presidente Ernesto Zedillo en lugar de desarrollar sus propias páginas de Internet tenía unas páginas oficiales hospedadas en el sitio de un tal señor Dávila quien en ese año de 1995 fungía como asesor de la Dirección General de Comunicación Social de la Presidencia de la República. La dirección del sitio del gobierno mexicano entre 1995 y 1996 era: http://www.davila.com.mx/presid/mexico.htm (Oliva Posada, 1996). Incluso antes de que el gobierno mexicano tuviera páginas en Internet, el Ejército Zapatista de Liberación Nacional ya tenía sus informes en la red debido a que el profesor Justin Paulson, miembro del Consejo de Estudios en Historia de la Conciencia de la Universidad de California, en Santa Cruz, California, Estados Unidos, emprendió el desarrollo de éstas a principios de 1994 (Islas y Gutiérrez, 2006).

Es hasta septiembre de 1996 cuando empezó a operar el Sistema Internet de la Presidencia de la República, el cual fue desarrollado por el Tecnológico de Monterrey, Campus Estado de México, publicando, en primer lugar, el Segundo Informe de Gobierno del Presidente Ernesto Zedillo. Otras Secretarías también se interesaron en tener sus páginas en Internet y ya para octubre de 1996 según información de NICMéxico el número de dominios .gob.mx era de 63 (Islas y Gutiérrez 2006). Más adelante, la elaboración de las páginas de la presidencia fueron encargadas a la Dirección de Publicaciones, la cual, en 1998 rediseña sus páginas con la finalidad de asumir la responsabilidad que había querido evadir a propósito los sucesos relativos a la guerrilla en Chiapas y a las muertes acaecidas en Acteal. Las páginas de Internet serían finalmente utilizadas para difundir la postura gubernamental ante tales acontecimientos (Islas y Gutiérrez, 2006). ${ }^{39}$

\footnotetext{
${ }^{39}$ Cabe señalar que los hackers mexicanos aparecen en escena cuando a partir de 1998 atacan los sitios WWW de algunas instituciones del gobierno mexicano. El 4 de febrero de 1998, X Ploit Team, un grupo de hackers mexicanos, reemplazó el logotipo oficial de la Secretaría de Hacienda por la imagen de Emiliano Zapata, con el siguiente texto
} 
Durante el gobierno del presidente Vicente Fox en 2001 se crea el Sistema Nacional eMéxico del cual se encargaría la Secretaría de Comunicaciones y Transportes. Éste tenía el objetivo de:

Reducir la brecha digital entre México y el mundo; entre el gobierno, las empresas, las familias; incrementar la penetración y cobertura de servicios como telefonía e Internet, así como servicios afines; eliminar barreras de acceso a la información, el conocimiento, los servicios y los mercados; facilitar el acceso a diversos servicios como salud, educación, comercio, y los servicios y trámites del gobierno; incorporar a las pequeñas y medianas empresas, así como a los microproductores artesanales y de diversas actividades regionales en la denominada nueva economía; eliminar cadenas de intermediarios que no agreguen valor a las actividades productivas y comerciales de las empresas; difundir nuestra riqueza pluricultural, así como los atractivos naturales y turísticos que México ofrece al mundo. (Margáin y Compeán, 2001).

En 1999 a iniciativa de la UNAM en México se formó un consorcio de universidades para participar en el desarrollo de la Internet 2: la Corporación Universitaria para el Desarrollo de Internet A.C. (CUDI). Actualmente 103 universidades y una secundaria en México tienen conexión a Internet 2, entre ellas la UNAM, UAM, ITESM, IPN y UdeG, ésta conexión fue donada por Telmex y Avantel, miembros de la CUDI y se prevé que pronto llegue a los hogares (Martínez, s/a). ${ }^{40}$

\footnotetext{
"Nuestra afiliación no es ninguna, no pertenecemos al EZLN, pero este es nuestro derecho de libre expresión como mexicanos” (Islas y Gutiérrez, 2006).

${ }^{40}$ Para el 2005 la red de CUDI contaba con una infraestructura de más de 8,000 kilómetros de enlaces de alta capacidad que operaba a una velocidad de 155 megabits por segundo. Esta red dorsal abarca todo el territorio nacional. Además se contaba con tres enlaces de la misma velocidad que permiten la interconexión con las principales redes académicas de Estados Unidos y del resto del mundo. A través de estos enlaces es posible tener acceso a más de 45 redes similares de Europa, Asia, Oceanía y América Latina que interconectan a más de 3,000 universidades y centros de investigación. (Pineda, 2005)
} 


\section{Glosario}

ARPANET. Es la primera red, antecedente de la red Internet, creada en 1969 por encargo del Departamento de Defensa de los Estados Unidos para comunicar entre sí a varios puntos del país y ser así, según el muy popular mito de su creación, una red de comunicación que funcionara incluso después de un ataque nuclear. Su nombre viene de las siglas en inglés Advanced Research Projects Agency Network.

BASIC. Es el acrónimo de Beginners All-purpose Symbolic Instruction Code o “código de instrucciones simbólicas de propósito general para principiantes”. Es un conjunto de lenguajes de programación que se extendió rápidamente entre las micro-computadoras caseras en Estados Unidos en la década de 1980 al ser interactivo y fácil de usar. Este lenguaje fue inventado en 1964 por John George Kemeny (1923-1993) y Thomas Eugene Kurtz (1928-) en el Dartmouth Collage, por lo que se le conoce también como el BASIC Dartmouth.

BITNET. Era una red cooperativa entre universidades norteamericanas fundada en 1981 en la City University of New York (CUNY) y la universidad de Yale. A diferencia de Internet esta red solamente iba de un punto a otro, los correos electrónicos eran transmitidos de un servidor a otro hasta que llegaban a su destino. La frase original que dio nombre a BITNET fue "Because It's There Net" y posteriormente fue adoptado el lema "Because It's Time Net".

BLOG. Viene de Weblog o cuaderno de bitácoras. Es un sitio en la red en el que se almacenan textos de manera cronológica, apareciendo en primer lugar el más reciente. Los textos pueden ser introducidos por una o más personas. El término 'weblog' fue creado por John Barger en diciembre de 1997 y la forma de 'blog’ la ideó Peter Merholz quien dividió la palabra weblog en la frase 'we blog' en su blob Meterme.com en 1999. En la actualidad los blogs son muy populares y los hay de diferentes temas como tecnología, vida personal, cultura, política, etc. Por otro lado el BLOGGER es la dirección que da el servicio para poder elaborar un blog.

CHAT. Esta palabra se refiere a la comunicación escrita simultánea a través de Internet entre dos o más personas. Entre los protocolos que cumplen con este objetivo están X- 
Chat, Chatzilla o el mIRC que utilizan el protocolo IRC (Internet Relay Chat). También están los protocolos agrupados en la mensajería instantánea como el MSN Messenger, Yahoo! Messenger, Jabber o ICQ.

COMUNIDAD VIRTUAL. Es una comunidad cuyos vínculos, interacciones y relaciones tienen lugar en el espacio de la red Internet. Una comunidad virtual está formada por gente que desea interactuar y comparten un propósito común, asimismo, tiene una política que guía las relaciones y un sistema que media las interacciones. Hay diferentes tipos de comunidades virtuales, por ejemplo, los foros de discusión, los newsgroups, el chat, pero en la actualidad entre los jóvenes son famosos los servicios de HI5, CHIDO GUEY y MY SPACE para establecer comunidades virtuales.

INTERNET. Una serie de computadoras capaces de comunicarse a través de su propio lenguaje, el protocolo TPC/IP. Más ampliamente, el término Internet se emplea para referirse a un conjunto de programas que habilitan determinados tipos de comunicación e intercambio de información.

INTERNET 2. La red Internet 2 es entonces una nueva etapa del desarrollo técnico que vuelve a partir del ámbito académico. Se tiene previsto que la red Internet siga como hasta hoy con un uso comercial y la red Internet 2 sea utilizada solamente para fines educativos, de colaboración científica e investigación, volver pues, a los orígenes académicos de este artefacto.

ICQ. Viene de "I see you” o "te busco”. Es un servicio de mensajería instantánea que fue el primero de este tipo en Internet. Fue creado por la empresa de software israelí Mirabilis a fines de la década de los noventa. En 1998 esta compañía fue adquirida por AOL (America on Line).

iPOD. Es un reproductor de música digital con una pantalla de color y un disco duro creado por Apple Inc. El iPOD puede ser utilizado como disco duro externo al ser conectado a un ordenador. La marca iPod procede de la unión del prefijo 'i' con la palabra 'pod'. Esta última es sacada de la película 2001: A Space Odyssey de Stanley Kubrick precisamente de las cápsulas blancas para actividades extravehiculares de que estaba dotada la famosa nave espacial Discovery. La 'i' hace alusión a su relación con la 
Internet y a que toda la serie de artículos de esta compañía tienen a la 'i' como su característica principal.

Laptop. Es una computadora móvil o una ‘computadora-cuaderno'. Es menos potente que una computadora personal (PC) o de escritorio aunque cumple con las mismas funciones que ésta última. La primera computadora móvil comercial fue la Osborne 1 creada en 1981, aunque era muy grande y pesada a comparación de las Laptops actuales, sin embargo, fue muy revolucionaria ya que permitió que los profesionales o empresarios llevaran con ellos sus datos a cualquier lugar.

MAC. Es el sistema operativo de la familia de computadoras Macintosh. En 1997 se nombró a Steve Jobs gerente de Apple y decidió introducir un nuevo sistema operativo tomando como punto de partida a Nextstep (sistema operativo orientado a objetos) y sustituir así el Mac OS clásico.

MESSENGER. Programa para enviar mensajes instantáneos a través de la red Internet. Según La Enciclopedia Wikipedia en línea, también se le llamó así a una misión de la NASA que envió una nave al planeta Mercurio en 2004.

PC. Computadora Personal. En 1976 Ed Roberts construyó una caja de cálculo con el nombre de Altair, la cual estaba hecha como una computadora de pequeña escala en torno a un microprocesador. Esta fue la base del diseño de la Apple I y la Apple II, la primera microcomputadora comercializada con éxito, construida en el garaje de las casas paternas por dos jóvenes que también habían abandonado los estudios: Steve Wozniak y Steve Jobs en Menlo Park, Sillicon Valley.

POST. Mensaje escrito, artículo o entrada nueva que se deja en los Weblogs. La acción de hacerlo se denomina "postear".

WWW. La World Wide Web es un lenguaje de descripción de documentos HyperText Markup Language o HTML en la que los estos documentos están situados en servidores con una dirección URL. El objetivo de Tim Berners-Lee, el principal autor del proyecto de la WWW, era establecer vínculos entre las informaciones descentralizadas en diferentes máquinas. 


\section{Bibliografía}

Adame, Miguel Angel

2005 "Hacia una socio-antropología de la vida cotidiana y su crítica” en Revista Casa del Tiempo [En línea] Vol. VIII, Época III, No. 88, 2005 en:http://www.difusioncultural.uam.mx/revista/mayo2005/adame.html

Adler L., Larissa y Marisol Pérez

1993 Una familia de la élite mexicana. Parentesco, clase y cultura 18201980. México, Alianza Editorial. [Primera edición en inglés: $A$ Mexican Elite Family, 1820-1980. Kinship, Class and Culture, Pricenton University Press, 1987].

Anderson, Benedict

1991 Imagined Communities: Reflections on the Origin and Spread of Nationalism. Londres, Verso. [Primera edición en inglés 1983. Trad. esp.: Comunidades imaginadas, México, Fondo de Cultura Económica, 1993].

Bourdieu, Pierre

1997 Razones prácticas. Sobre la teoría de la acción. Barcelona, Anagrama. [Primera edición: Raisons pratiques. Sur la théorie de l'action, Éditions du Seuil, París, 1994].

Bourdieu, Pierre

2002 La distinción. Criterio y bases sociales del gusto. Buenos Aires, Taurus. [Primera edición en francés: La distinction, Les Éditions de Minuit, 1979]

Briggs, Asa y Peter Burke

2002 De Gutenberg a Internet. Una historia social de los medios de comunicación. Madrid, Taurus Historia. [Título original: A Social History of the Media. From Gutenberg to the Internet].

Castells, Manuel

1999 La era de la información. Economía, sociedad y cultura. La sociedad red. Volumen 1. México, Siglo XXI. [Primera edición en inglés: The information age: economy, society and cultura. The rise of the network society, Blackwell Publishers 1996].

Cebrián, Juan Luis

2000 La red. Segunda edición, España, Santillana. [Primera edición 1998].

De Garay, Adrián

2004 Integración de los jóvenes en el sistema universitario. Barcelona, Ediciones Pomares. 
Downey, G.L., J. Dumit y S. Williams

1995 “Cyborg Anthropology” en Cultural Anthropology, 10 (2), pp. 265-269 citado en Mayans i Planells, Joan "Nuevas Tecnologías, Viejas Etnografías. Objeto y método de la antropología del ciberespacio" 2002b. Disponible en Revista Quaderns de l'ICA [En línea] 17-18, pp. 79-97 en el Archivo del Observatorio para la CiberSociedad en: http://www.cibersociedad.net/archivo/articulo.php?art=23

Featherstone, Mike

1991 Cultura de consumo y postmodernismo. Argentina, Amorrotu. [Publicado simultáneamente por Sage Publications de Londres, Thousand Oaks y Nueva Delhi como Consumer Cultura and Postmodernism].

Flecha, Ramón, Jesús Gómez y Lidia Puigvert

2001 Teoría sociológica contemporánea. Barcelona, Paidós Studio.

Flichy, Patrice

1993 Una historia de la comunicación moderna: espacio público y vida privada. México, Gustavo Gili. [Primera edición en francés: Une histoire de la communication moderne. Espace public et vie priveé, Éditions La Découverte, 1991].

Flichy, Patrice

2003 Lo imaginario de Internet. España, Tecnos. [Primera edición en francés: $L$ ' imaginaire d'Internet, Éditions La Découvert y Syros París, 2001].

García Canclini, Néstor

2004 Diferentes, desiguales y desconectados, Barcelona, Gedisa.

Giddens, Anthony

1991 Modernidad e Identidad del Yo. El yo y la sociedad en la época contemporánea. Barcelona, Ediciones Península. [Título original: Modernity and Self Identity: Self and Society in the Late Modernity Age, Standford University Press].

Giddens, Anthony

1993 Las nuevas reglas del método sociológico. Buenos Aires, Amorrotu. [Primera edición en ingles: New rules of sociological method: A positive critique of interpretative sociologies, Hutchinson, London, 1976].

Giménez, Gilberto

2005 "La concepción simbólica de la cultura” en Teoría y análisis de la cultura. Volumen uno. México, CONACULTA. 
Glick, Thomas

2000 “Difusión. Difusionismo” en Barfield, Thomas (Ed.) Diccionario de antropología. México, Siglo XXI. [Primera edición en inglés: The dictionary of anthropology, Blackwell, 1997].

Goffman, Erwing

1989 La presentación de la persona en la vida cotidiana. Buenos Aires, Amorrotu. [Primera edición en inglés The presentation of Self in Everyday Life, 1959].

Green, Leila 2002 Communication, technology and society. Londres, Sage.

Gutiérrez, Fernando y Octavio Islas 1998 “El diálogo de la comunicación” en Razón y palabra. Revista electrónica [En línea] Número 10, Año 3, Abril-Junio 1998 en: http://www.razonypalabra.org.mx/anteriores/n11/editc11.html

Hart, Keith

2004 "Notes towards an anthropology of the Internet” en Revista Horizontes Antropológicos [En línea] Porto Alegre, año 10, junio-julio 21, pp. 1540 en: http://www.scielo.br/scielo.php?script=sci_arttext\&pid=S010471832004000100002 [Accesado el 28 de abril de 2006].

Habermas, Jürgen

1988 "Modernidad: un proyecto inacabado" en Jürgen Habermas. Ensayos Políticos. Traducción de Ramón García Cotarelo. Barcelona, Península. [Conferencia pronunciada el 11 de septiembre de 1980].

Hernández, Laura

2006 "Desarrollo de Internet en México. Algunos efectos sociales y tecnológicos” en Sociedad de la Información y el Conocimiento [En línea] e-México, UNAM, 2007 en: http://www.sociedadinformacion.unam.mx/ index.jsp?pagina $=$ desarrollo\&action $=$ vrArticulo\&aid $=65$ (Accesado el 23 de marzo de 2007].

Hine, Christine

2004 Etnografía virtual. Barcelona, UOC. [Primera edición: Virtual Etnography, Sage Publications, 2000].

Islas, Octavio y Fernando Gutiérrez

2003 "El medio que cambió la comunicación” en Revista Mexicana de Comunicación [En línea] Número 83, Septiembre-Octubre 2003, en: http://www.mexicanadecomunicacion.com.mx/ Tables/RMC/rmc83/medio.html\#8

Klein, Naomi 2000 No Logo. El poder de las marcas. México, Paidos. [Publicado en inglés por Alfred A. Knof Canada]. 
León, Emma

1999 Usos y discursos teóricos sobre la vida cotidiana. España, Anthropos, UNAM, CRIM.

Livingstone, Sonia

2002 Young people, new media. Childhood and the changing media environment. Londres, Sage.

Mayans i Panells, Joan

2002 Género chat o cómo la antropología puso un pie en el ciberespacio. Barcelona, Gedisa.

Mayans i Planells, Joan

2002b "Nuevas Tecnologías, Viejas Etnografías. Objeto y método de la antropología del ciberespacio" en Revista Quaderns de l'ICA, 17-18, pp. 79-97. Disponible en el Archivo del Observatorio para la CiberSociedad en línea en: http://www.cibersociedad.net/archivo/articulo.php?art=23

Margáin y Compeán, Julio César

2001 "Sistema e-México: Convergencia Tecnológica con Equidad” en Mercado de Valores, p. 3 citado en Islas, Octavio y Fernando Gutiérrez "El medio que cambió la comunicación” en Revista Mexicana de Comunicación [En línea] Número 83, Septiembre-Octubre 2003, en: http://www.mexicanadecomunicacion.com.mx/

Tables/RMC/rmc83/medio.html\#8

Martínez, Jorge Rafael

s/a La I2” en Enseñar a educar [En línea] en:

http://eae.ilce.edu.mx/internet2.htm\# [Accesado el día 23 de marzo de 2007].

Mc Quail, Denis

1994 Introducción a la teoría de la comunicación de masas. Tercera edición revisada y ampliada, Barcelona, Paidós. [Publicado en inglés como Mass Communication Theory (Third Edition), Sage Publications of London, Thousand Oaks y Nueva Delhi, 1994].

Mead, Margaret

1995 Adolescencia y cultura en Samoa. Barcelona, Paidós. [Primera edición en inglés: Coming on Age in Samoa, 1971].

Mead, Margaret

1997 Cultura y compromiso. Estudio sobre la ruptura generacional. Barcelona, Gedisa. [Edición en inglés: Culture and commitment. A study of the generarion gap, Natural History Press, 1970]. 
Miller, Daniel y Don Slater

2000 The Internet. An ethnographic Approach. Estados Unidos, Oxford, Estados Unidos.

Morley, David

1996 Televisión, audiencias y estudios culturales. Buenos Aires, Amorrotu Editores. [Primera edición en inglés: Television, Audiences and Cultural Studies, Routledge, Londres, 1992].

Moscovici, Serge

1961 El psicoanálisis, su imagen y su público. Buenos Aires, Humeal.

Murdock. G., P. Hartman, P. Gray

1995 "Contextualizing home computers: resources and practices”, en N.

Heap, R. Thomas, G Einon, R. Mason, and H. Mackay (eds.)

Information, Technology and Society: A Reader. Londres, Sage, citado en Livingstone, Sonia, Young people, new media. Childhood and the changing media environment, Londres, Sage, 2002.

Oliva Posada, Luis

1996 “Segundo informe de gobierno" en Gobierno Digital. Número 6, citado en Islas, Octavio y Fernando Gutiérrez "El medio que cambió la comunicación” en Revista Mexicana de Comunicación [En línea] Número 83, Septiembre-Octubre 2003, en:

http://www.mexicanadecomunicacion.com.mx/

Tables/RMC/rmc83/medio.html\#8

Pinch, Trevor J. y Wiebe E. Bijker

1994 "The Social Construction of Facts and Artifacts: or How the Sociology of Science and the Sociology of Technology Might Benefit Each Other” en Bijker, Wiebe E., Thomas P. Hughes, Trevor J. Pinch (eds.) The Social Construction of Technological Systems, Estados Unidos, MIT. [Primera edición: 1989]

Pinch, Trevor

1997 “La construcción social de la tecnología: una revisión” en Santos, María Teresa y Rodrígo Díaz Cruz (comp.) Innovación tecnológica y procesos culturales. Nuevas perspectivas teóricas. México, UNAM, FCE, Ediciones Científicas Universitarias, pp. 19-50.

Pineda, Mauricio

2005 "La convergencia de las Telecomunicaciones” en eSemanal en Internet [En línea] Número 676, 4 de noviembre de 2005 en: http://www.esemanal.com.mx/

articulos.php?id_sec=7\&id_art=2815\&id_ejemplar=144

Reguillo, Rossana

2000 "Las culturas juveniles: un campo de estudio. Breve agenda para la discusión” en Gabriel Medina Carrasco (comp.) Aproximaciones a la diversidad juvenil. México, El Colegio de México, pp. 19-44. 
Roberts, Brian

2006 Micro Social Theory. New York, Palgrave Macmillan.

Robles, Oscar

2000 "Evolución de Internet en México y en América Latina” en Octavio

Islas y Fernando Gutiérrez. Internet el medio inteligente. México, Tec de Monterrey, CECSA.

Robles, Oscar

2007 "El primer nodo de Internet en México” en Pioneros de Internet. La historia por sus protagonistas [En línea] disponible en:

http://interred.wordpress.com/2007/02/17/el-primer-nodo-internet-enmexico/\#comment-21 [Accesado el día 28 de marzo de 2007].

Rojo, Pedro Antonio

2003 Sociedad global y nuevas tecnologías de la información. España, Universidad Católica de San Antonio.

Santos, María Teresa y Rodrigo Díaz Cruz

1997 “Artefactos sociotécnicos, cultura y poder: Hacia una antropología de la innovación tecnológica” en Innovación tecnológica y procesos culturales. Nuevas perspectivas teóricas. México, UNAM, FCE, Ediciones Científicas Universitarias, pp. 48-60.

Segalen, Martine

1992 Antropología histórica de la familia. México, Taurus Universitaria. [Título original: Sociologie de la famille, Armand Collin Editeur, Paris, 1981].

Silverstone, Roger y Leslie Haddon

1996 "Design and the Domestication of Information and Communication Technologies: Technical Change and Everyday Life” en Mansell, Robin y Roger Silverstone. Communication by design. The politics of information and communication technologies. Gran Bretaña, Oxford University Press, pp. 45-74.

Surrat, Carla G.

2001 The Internet and Social Change, North Carolina USA, McFarland \& Company Publishers.

Thompson, John B.

1998 Los media y la modernidad. Una teoría de los medios de comunicación. España, Paidós. [Título original: Media and Modernity. A Social Theory of the Media, Stanford University Press, 1995].

Touraine, Alain

2006 Crítica de la modernidad. México, Fondo de Cultura Económica. [Primera edición en francés: Critique de la modernité, Librairie Arthéme Fayard, 1992]. 
Velázquez, Lourdes, Genevive Lucet y Hans Ludwing Reyes

2004 “Internet 2” en Enter@te en Línea [En línea] disponible en:

http://www.enterate.unam.mx/Articulos/2004/noviembre/internet2.htm

[Accesado el día 30 de marzo de 2007].

Wikipedia. La Enciclopedia Libre.

2007 “BITNET” en Wikipedia. La Enciclopedia Libre [En línea] Abril de 2007 disponible en http://en.wikipedia.org/wiki/Bitnet

[Accesado el día 28 de abril de 2007].

Wittel, Andreas

2000 "Ethnography on the move: From field to net to Internet" en Forum: Qualitative Social Research [En línea] disponible en:

http://www.qualitative-research.net/fqs-texte/1-00/1-00wittel-e.htm

[Accesado el día 4 de abril de 2006].

Wolf, Mauro

1994

La investigación de la comunicación de masas. Crítica y perspectivas.

México, Paidós. [Publicado en italiano como Teorie delle comunicación di masa, Bompiani, Milán 1987]. 